\title{
Children and citizenship
}

Jean Hine 


\section{Children and citizenship}

Jean Hine

Online Report 08/04 


\section{Acknowledgements}

This research would not have been possible without the considerable support of the On Track Project Co-ordinators in the areas where the fieldwork took place. I am most grateful to them for facilitating the links with key individuals locally who were able to make this project happen within the very short time that was available. I would also like to thank those many individuals in On Track and associated projects who welcomed and assisted us in organising the work with children and young people.

As author of this report and principal investigator, I am indebted to the team of researchers that implemented this project and undertook all of the fieldwork and much of the analysis. I am particularly grateful to Sarah Cooper and Insan Fathallah-Caillau, the main researchers, for their commitment and contribution to this project and for helping me clarify and develop my thinking about many of the issues that emerged in relation to the concept of citizenship and children. Especial thanks go to Sarah for her invaluable contribution to the final analysis.

Above all, thanks must go to the children and young people who enthusiastically participated in our groups. They made the work enjoyable as well as interesting, and I hope this report does justice to their contribution.

Jean Hine, Department of Sociological Studies and School of Education, University of Sheffield 


\section{Contents}

Acknowledgements

Executive summary

1. Introduction

1

Research objectives 1

2. Citizenship 3

The policy context 3

Citizenship and the National Curriculum 4

$\begin{array}{lr}\text { Historical understandings of citizenship } & 6\end{array}$

3. Methodology 7

$\begin{array}{ll}\text { Children and research } & 7\end{array}$

The value of focus groups

Design of the focus groups 9

$\begin{array}{lr}\text { The research project implementation } & 10\end{array}$

4. The voices of the children and young people 14

$\begin{array}{lr}\text { Social and moral responsibility } & 14\end{array}$

$\begin{array}{ll}\text { Community involvement } & 27\end{array}$

$\begin{array}{ll}\text { Teenagers: troublesome or troubled? } & 29\end{array}$

People in authority 30

Diversity 31

Social capital 33

Political literacy $\quad 35$

Citizenship 37

5. Conclusions 39

A safe place to grow up $\quad 39$

Diversity 39

Education for citizenship $\quad 40$

Justice $\quad 41$

$\begin{array}{ll}\text { Politics } & 41\end{array}$

$\begin{array}{ll}\text { References } & 42\end{array}$

Appendix: Sample details $\quad 45$ 


\section{Executive summary}

This research was funded by the Home Office as a small complementary study to the National Evaluation of On Track. On Track is a pilot project for the comprehensive provision of early and multiple interventions for children and families in areas of high deprivation and high crime. Twentyfour pilot projects in England and Wales are delivering services with the aim of reducing the risks of children becoming involved in anti-social and criminal behaviour.

- This piece of work was designed to explore children's understanding of the three elements of citizenship identified by the report of the Advisory Group on Citizenship (DfEE, 1998): social and moral responsibility, community involvement, and political literacy. The research was undertaken in seven On Track project areas and one pilot area, which also has high deprivation. In total 269 children aged between seven and 15 took part.

- Children generally understand the reasons for rules and accept their legitimacy, though they do question some of them. They report finding it easier to renegotiate rules at home than at school.

- Children usually comply with rules, commonly because they feel it is the right thing to do. Rules that they view as "silly", or see are not being enforced, are less likely to be observed. Reasons for not complying with rules include peer pressure, it feels good, feeling there is no alternative course of action, and that sometimes it happens unintentionally.

- The biggest complaint by children, particularly about the school environment, was that they are not listened to. Few of the children felt that they had any real say at school. A few schools had participatory systems to encourage children to become involved in the decision-making in school, but many of the children were sceptical of these schemes where they thought their involvement was tokenistic.

- Children are quick to spot unfairness, especially where they feel that rules are not being applied reasonably. Children complained of rules that adults enforced but did not abide by themselves.

- Children have two main responses to wrongdoing: retribution and restoration. Although their immediate suggestions for responding to wrongdoing may often be punitive, most children spontaneously demonstrated an understanding of the perspective of the victim and a concern to put right the wrong that had been done, often suggesting some sort of restitution.

- Most children found something positive to say about their neighbourhood. When they were critical, it was often about community safety issues in local public places: syringes in parks, rubbish and untidiness, dangerous pavements.

- The most common complaint from children about their neighbourhood was in relation to how they spend their time: younger children wanted safe, clean places to play, and older children wanted more facilities and things to do.

- A major concern for many children, particularly primary school children, is "teenagers". This is related to reports of acts of antisocial behaviour and general intimidation.

- The children reported very limited involvement in formal voluntary activity, but they do undertake informal "helping" activities on a much greater scale.

- The children and young people showed an interest in and knowledge of political issues. Much of it was tinged with cynicism about national and local politics. 


\section{Introduction}

This piece of research is timely, providing as it does insights into issues which are fundamentally important to helping children and young people become the "active citizens" aimed for by current government policy. The findings emphasise that children are not a homogenous group and should not be treated as such by policy makers. Even within limited age bands there is a wide range of views and abilities.

The results show that, even at a young age, children have sophisticated reasonings and understandings of complex issues. They navigate a wide range of rules imposed primarily at home and at school, and this work shows that they generally accept and understand the legitimacy of these rules and are happy (more or less) to comply with them. They do question these rules and know how to renegotiate some of them, particularly at home. They are very quick to spot unfairness in the enforcement of rules. There are occasions when they will disobey rules, particularly where they cannot understand, or do not accept, the reasoning for the rule. Unsurprisingly, as children grow older they are more likely to question these rules, and in that process allow themselves to break more rules. But generally and overwhelmingly the message from this work is that children and young people are very rule abiding.

The children and young people who took part in this study live in deprived areas, often with high crime rates - areas where levels of community involvement and social capital are generally thought to be low. Membership of formal clubs or groups is indeed minimal, but this study reveals a surprising amount of informal community involvement which shows how these children care for others in their community, even though they may not be very happy with the physical environment in which they live and can identify significant problems there.

The third focus of this small piece of work was political literacy, and here we find perhaps unexpectedly high levels of knowledge about how government works, though admittedly with some substantial misconceptions. Worryingly, there are early signs of cynicism with the political system, even at very young ages, which may lead to apathy and a lack of involvement in voting such as that reflected in the poor turnout of young people at the last general election.

This study aimed to explore the understanding of citizenship held by children and young people, using the three dimensions of citizenship identified by the Crick report (DfEE, 1998) as a framework: social and moral responsibility, community involvement, and political literacy. The voices of children frequently not heard in such research - travellers, offenders, refugees - are included. The study explores their feelings and views about these aspects of citizenship, and will provide insights into how young people develop identities as citizens.

The children's voices are presented directly as much as possible within this report, in an attempt to provide a proper reflection of the variety of their views and responses. The report draws out common themes, but uses their words with minimal adult academic interpretation.

\section{Research objectives}

The objectives of this research were to:

- Describe children's understanding of rights and responsibilities, in particular exploring the notion of civic responsibility.

- Describe children's feelings of belonging and inclusion, and the opportunities available to them to contribute to their communities and to ascertain their involvement in both antisocial and pro-social activities.

- Explore the factors which shape children's views: family, media, school, friends.

- Compare the perspectives of children from different groups: e.g. age, gender, ethnicity, faith.

- Examine the understandings of children excluded from the mainstream, such as young offenders, and pupils excluded from school. 
The research was funded by the Home Office Research, Development and Statistics Directorate, and carried out as a complementary piece of work to the National Evaluation of On Track. ${ }^{1}$ On Track was developed as a component of the Crime Reduction Programme of the Home Office, and is now managed by the Children and Young People's Unit. It is an innovative project designed to provide early multiple interventions for children and families, with the aim of reducing the risk of children becoming involved in criminal and antisocial behaviour. The locations for the On Track projects were chosen as areas of high deprivation and high crime. This research was undertaken in seven of those project areas.

\footnotetext{
${ }^{1}$ France et al, 2004
} 


\title{
2. Citizenship
}

\author{
The policy context
}

Citizenship is a concept which enjoys cross party support. A Commission on Citizenship was established in 1988 by the Conservative Government. It reported in 1990, adopting as its starting point an understanding of "active citizenship" as defined by Marshall (1950). The report stressed that welfare should be widened to include what people can do for each other in their local community as well as what they can expect from the State, and placed a heavy emphasis on volunteering as a civic virtue which should be recognised and rewarded.The Commission also recommended the incorporation of considerations of citizenship in all programmes of education and training in schools, adult education and professional education.

This recommendation was taken forward by the Labour government and has been integrated into the national curriculum.

The introduction of Citizenship into the curriculum in all secondary schools from this September will help young people understand their role and responsibilities in a democratic society and contribute to their sense of values and identity. (Demos Lecture by Estelle Morris, Secretary of State for Education and Skills, 21 March 2002).

The idea of "active citizenship" was taken on board with the establishment of the Active Community Unit within the Home Office, which introduced a biennial citizenship survey in 2001, emphasising the importance of this concept of "citizenship" to the government. That survey is designed for adults, those aged 16 and over: the research reported here was focused on children and young people aged seven to 15 , and will provide an interesting complement to the national citizenship survey.

The reasons for policy makers' interest in active citizenship are various, but there are two particular concerns of government, which are addressed by the agenda: electoral participation and youth crime. Roche (1999) suggested that children tend to be viewed simply as "trouble" or "in trouble". There is a danger that citizenship education is being seen as a panacea for many ills, and that in relation to children the "citizenised" child will be neither.

\section{Electoral participation}

Many observers have commented that today's young adult generation participates very little in conventional politics (such as voting or joining political party organisations) and has a declining level of trust in public institutions (Blackman and France, 2001; Tate, 2001; Buckingham, 2000; Park et al, 1999). Concern about young people's participation in societal, political, economic, and community institutions is supported by many social surveys (see Bhavnani, 1991; Parry et al., 1992; BYC 1995; Heath and Jowell, 1997; and White, Bruce, and Ritchie, 2000). Some attribute this to problems in adolescence and to young adulthood, to increasing gaps between the opportunities available to young people from different socio-economic groups, and to a decline in sense of civic responsibility.

There is growing concern that young people are becoming increasingly uninterested in politics. In her conclusions to a chapter on political apathy for the Young People's Social Attitudes Survey, Park (1999) noted that,

In all instances where it is possible to monitor change over time, teenagers and young adults have moved away from an involvement in conventional politics. They are, for instance, less interested than they were four years earlier, less knowledgeable, and less likely to have formed an attachment to any party. (p37)

That survey also highlighted how younger generations are less inclined to view voting as a civic obligation.

Blame is attached to parents, peer groups, the media, and public officials; while others charge schools with failing children as citizens. Few studies have looked in depth at what children and young people think and feel about their experiences and expectations. 
The problem of youth crime is high on the political agenda, and links are often made with the citizenship agenda as a means of deterring young people from antisocial and criminal behaviour. The Social Exclusion Unit made the link in their report of Policy Action Team 12: Young People, where the citizenship curriculum was identified as a means of "discouraging antisocial behaviour by young people".

The view that a good and active citizen is one who is law-abiding is also often made by politicians, for example, the Minister for Young People said in the Government's Response to the UK Youth Parliament's 2001 Manifesto:

"..lessons in citizenship provide opportunities for the promotion of pupils' spiritual, moral, social and cultural development which will teach them to be respectful of all people, not to stereotype or pre-judge them, and to be committed to society, to community and themselves, developing an understanding of right and wrong, and fairness and obligations." (DfEE, 1998)

Certainly understandings of right and wrong and respect for the law are essential aspects of the report of the Advisory Group on Citizenship (DfEE, 1998: 10).

\section{Citizenship and the National Curriculum}

Citizenship education aims to give children the opportunity, skills and knowledge to become a good and active citizen and to develop children's "democratic skills and dispositions of concern and respect for others" (The Citizenship Foundation, 1998:12). The general consensus within citizenship literature is that citizenship not only entails political awareness and involvement but also personal and social development.

So our understanding of citizenship education in a parliamentary democracy finds three heads on one body: social and moral responsibility, community involvement and political literacy. (DfEE, 1998:13)

\section{Social and moral responsibility}

The Crick Report states that social and moral responsibility is encouraged by

children learning from the very beginning self-confidence and socially and morally responsible behaviour both in and beyond the classroom, both towards those in authority and towards each other ... guidance on moral values and personal development are essential preconditions of citizenship. (ibid:11)

This implies that children and young people should be made aware of their responsibilities to themselves and others, in terms of their duties and obligations to family, friends, school, community, state and society. The concept of responsibility itself is defined in the Crick report in general terms as,

(a) care for others; (b) premeditation and calculation about what effect actions are likely to have on others; and (c) understanding and care for the consequences. (ibid:13)

Morality covers values that we hold about what is right or wrong, good or bad. As stated in Good Thinking: Education for Citizenship and Moral Responsibility (The Citizenship Foundation, 2001), a guidebook for teaching citizenship, moral responsibility involves values such as:

Social justice; political equality; respect for difference; human rights; co-operation; civility; respect for the rule of law; and a commitment to negotiation and debate as the proper way to resolve disagreements over public policy. (p.3)

According to the Crick Report, even at primary school age,

children are already forming through learning and discussion, concepts of fairness, and attitudes to law, to rules, to decision-making, to authority, to their local environment and social responsibility etc (ibid:11) 
By far the most commonly discussed issues in relation to citizenship are rights and responsibilities, and the two are inextricably linked in a reciprocal relationship. The Home Office Citizenship Survey (Home Office, 2001) defined rights and responsibilities for the interviewers. The aim of the survey was to elicit people's views on their rights and responsibilities.

Rights are things you are entitled to: what 'we' can believe, say or do. Responsibilities are actions and decisions for which "we" are accountable: things we are obliged to do and things "we" feel "we" ought to do. (Progress Report Leaflet, 2001: 3)

There is a vast and growing literature about children's rights, and that was not a focus of interest in this study. Of particular interest here was trying to understand how children viewed their social and moral responsibilities, and in particular how they developed a sense of right and wrong. Understanding right and wrong is an intrinsic aspect of moral development.

\section{Community involvement}

The Crick Report (DfEE, 1998) identified community involvement as:

learning about and becoming helpfully involved in the life and concerns of their communities, including learning through community involvement and service to the community. (p12)

The idea is that through community involvement, and especially voluntary service, children and young people will absorb the values of the community and society, feel included in their local environment and have a sense of belonging. This will come about through taking part in community activities and giving service back to the community, working for the common good. Voluntary service and community involvement are seen as "necessary conditions of civil society and democracy", and are therefore necessary conditions of being a good and active citizen (DfEE, 1998:10). Much of this has been absorbed into government programmes such as the Active Community Unit, in an attempt to encourage feelings of belonging, respect for others in the community and caring for others and the environment.

\section{Political literacy}

Political awareness and involvement, along with knowledge of the law and justice are established facets of citizenship education. However, political literacy has grown to encompass much more then this. The Crick Report defines it as:

pupils learning about how to make themselves effective in public life through knowledge, skills and values...[including] discussion of the allocation of public resources and the rational of taxation. (ibid:13)

Buckingham (2000:2-26) suggests that a decline in interest in the news has resulted in a decrease in "informed citizenship" and that young people are becoming more alienated because traditional news media does not engage with the readers' lived experience. An alternative view is, however, that young people are accessing political information via alternative forms such as television and the Internet.

Political issues that are of concern to citizens include those issues that are in the public domain, such as laws, issues of fairness, distribution of services, equality, and rights and responsibilities. It is possible to see here that there is some overlap with social and moral responsibility, especially in terms of the law, justice and issues of fairness. Indeed social and moral responsibility can be viewed as one aspect of political literacy, but following Crick is dealt with separately in this work.

Political literacy incorporates notions of equality and empowerment. Citizenship education, particularly in France, is concerned with opening up the opportunities to become an active and good citizen to all members of communities and society (Osler A. and Starkey H, 2001). All members should have the opportunity to put their opinion forward, listen to the opinion of others, debate, and follow with decision-making and resolution. 


\section{Historical understandings of citizenship}

Although recently very high profile, "citizenship" is not a new nor a static concept - the notion itself expects citizens to contribute to and shape society. Citizenship was important to Ancient Greece and the Roman Empire and although their understanding of this term and what it meant was different to the meaning in use today, there are strands in common. As well as the historical/temporal dimension, it is also important to conceptualise citizenship in a global context. Recent world events have dramatically highlighted how they can impinge upon our understandings of society and citizenship, and the frequent re-shaping of international boundaries creates displaced citizens looking for a home.

Citizenship has no "essential" or universally true meaning; however, we can attempt some reasonable understanding of the main usages of the term in our society and the "great moral force behind what has come down to us historically". (Crick, 2000)

- In Ancient Greece and the Republic of Rome, a citizen was perceived as free, able to actively participate in the public and political life of a community.

- In the 17th century, English Liberal theorists Hobbes and Locke, building upon the classical tradition, defined the citizen as a male property owner, the individual whose interests government existed to serve.

- In the eighteenth century, a citizen of England was defined as anyone born in England, excepting children of foreign diplomats and occupying armies (Blackstone, 1765). Under the common law, a child born outside England was not an English subject, even if his [sic] parents were English subjects.

- The enlarged British Empire of the 19th century included a population which was largely not of English ancestry. Under British law at that time, anyone born in the Empire was a British subject and any British subject living in a parliamentary constituency (in the British Isles) could vote if he met the voter criteria (Dicey, 1950). In the 19th century, the foundations of social rights were laid, and for the first time education was seen as a necessary prerequisite to civil participation.

The foundation of contemporary thinking about citizenship in the UK can be seen in the works of T.H. Marshall (1950), who coined the term "active citizenship", defining it as an interaction between three elements: the civil, the political, and the social:

The civil element is composed of the rights necessary for individual freedom - liberty of the person, freedom of speech, thought and faith, the right to own property and to conclude valid contracts, and the right to justice. This shows us that the institutions most directly associated with civil rights are the courts of justice.

By the political element I mean the right to participate in the exercise of political power, as a member of a body invested with political authority or as an elector of the members of such a body. The corresponding institutions are parliament and councils of local government.

By the social element I mean the whole range from the right to a modicum of economic welfare and security to the right to share to the full in social heritage and to live the life of a civilised being according to the standards prevailing in the society. (pp:10-11)

Marshall associated civil rights with the end of the guild system and city-based restrictions on trade and commerce; he focused on the emergence of a market in labour and free trade within national boundaries, (1964:82). Political rights included the right to vote and to stand as a candidate. Social rights, such as the right to education, access to housing and health services or income security, are associated with a fundamental transformation of our thinking on equality from a formal principle (equality in status) to require some measure of socio-economic reality (equality in practice). 


\section{Methodology}

\section{Children and research}

Traditional research on childhood usually concentrated on the developmental stages of the child becoming an adult and reaching adult status. The key to this transition was the socialisation of children into adult thinking and acting, to responsible positions and behaviour, and to becoming a full citizen. This approach characterised children and young people in two significant ways: first it positioned young people as less developed and therefore "inferior" to adults, and second, it emphasised adult wishes to make transitions through the developmental stages easy and predictable. Since young people do not always conform to adult norms there was great interest from the 1970s in youth subcultures and different lifestyles. By the early 1990s research described numerous categories of at-risk youth, that is, those who are likely to fail to reach the full ideal adult status (Banks et al, 1992).

During the late 1980s new thinking on childhood started to emerge. James and Prout (1997) identified a tendency in traditional childhood theories to locate the child as a passive recipient of adult expectations. However, in their view children are social actors and as such have a say and influence over their environments.

Some recent research has been characterised by an examination of different categories of children and young people, such as those from different racial, class, gender, or sexuality backgrounds, and how their experiences and understandings of their worlds are shaped by these factors (Roberts, 1993). Researchers have drawn on cultural studies, feminisms, post-structuralisms, critical race theories, among others in describing and interpreting these various youth worlds. Mirroring the field of sociology, more generally, recent youth research has been linked to globalisation, citizenship, network societies, and increasing inequalities among youth. Interdisciplinary interest in geography appears in work on youth in time and place.

A significant complexity here is that there is not a common agreement among researchers or policymakers about the age boundaries of childhood, youth and adulthood. Western societies do not have a common view of the "the child", "childhood", "youth" and "adulthood". Differences may be legal, social and economic. For example, children cannot enter into legal contracts or legally own property until the age of 18 in England and Wales, though they can at the age of 16 in Scotland (Jones, 1994, in Coles, 1995).

For the purposes of this research, there is a focus on children between the ages of seven and 15 . There is little evidence of research on the three elements of citizenship, and there is a distinct lack of research around these themes in relation to younger children in particular. Research around young children tends to focus on attitude surveys, leisure pursuits, time use and lifestyles. Of the three themes identified, it is political literacy that has had most attention over the years and there is some evidence of this in relation to young people and youth research (Blackman and France, 2001; Buckingham, 2000; Park et al, 1999).

In contrast to adults, children have historically been seen as "irrational beings" whose accounts are not trustworthy and whose opinions are therefore of limited value (James and Prout, 1997). Until recently children were considered to be unreliable providers of information, mainly as a result of their perceived inability to express views about abstract concepts, their tendency to change their views, and to try to please adults or researchers (Young and Barret, 2001).

The ways in which researchers define children and their notions of childhood affect the methodological approaches and methods they use. As Ring (2000) argues,

The researcher, by moving the focus of interest from children as subjects to children as people, can show respect for children as citizens, not as adults in the making. (p1) 
Perceiving children as "people" and "citizens" in their own right is particularly important in this piece of research, and the design used focus groups as a means of achieving this. The focus group method chosen has theoretical, methodological and practical advantages.

The aim of this aspect of the work was to discover children's perceptions of caring for others, their ability to plan and calculate the effects of actions on others and their awareness of consequences, in terms of social and moral responsibility. This involves exploring children's understandings of what is good and bad, right or wrong; what is fair or not fair; how these are categorised; and how "bad behaviour" can affect others. Exploration of children's knowledge of rules and laws, if they feel these are necessary and how children and young people live with or fight against regulation, is also incorporated. In addition, social and moral responsibility involves understanding how children view other people's behaviour and how they discuss issues that are of concern to them.

\section{The value of focus groups}

There is an increasing body of literature about the use of focus groups in research with children, particularly research concerning child and adolescent risk behaviour (Barker and Rich, 1992; Croft and Asmussen, 1993; Houghton et al, 1995).

Carrying out focus groups with children is different in important respects to undertaking such research with adults, although the group dynamic remains centrally important in both cases. Focus groups seek to gain an understanding of how participants make sense of issues and themselves (Rubin and Rubin, 1995) by encouraging participants to express and exchange their views. The method takes advantage of how attitudes and opinions are developed through conversation and interaction with others.

The benefits of using focus group rather than individual interview include:

- The quality of data that the method can elicit. Greenbaum (2000) maintains that the group dynamic allows people to share their ideas with peers and so yield richer data than one-to-one interviews in many situations. Pragmatically, it does not require time to build up trust between an interviewer and participant as with one-to-one interviews.

- The synergistic effects of group involvement. The "security" of being with peers may prompt responses and breed the confidence to contribute to discussions. Stewart and Shamdasani (1990) argue that focus groups have a synergistic effect in the way that different strands of thought come together and are played out with one another.

- The ability to hear individual and group voices. Focus groups allow for the exploration of both individual and group voices and narratives as they are constructed within the group context. This was felt to be particularly important for this research where we were interested in common understandings and the ways that participants discuss and debate the topics (Sparks et al, 2000).

- Improved participation. Kruger and Tomasello (1986) maintain that children's concentration, reasoning and also their individual contributions to discussion are often improved when working within peer groups. Morrow (1999) found that knowing other children could be beneficial as children were used to discussing things together.

At the same time focus groups are not unproblematic. Morrow (1999) also reported that familiarity could cause difficulties; for example children referred to their own disputes and quarrels in ways that made it hard to relate to a specific issue that the interviewer was trying to cover. In addition, people have different personalities and moods, are willing to speak in differing amounts and even suppress certain comments because they do not want others in the group to know their feelings on a certain matter (Myers, 1983; Morgan, 1988). This must be addressed reflexively by the interviewer who is facilitating the discussion. It was decided that using two interviewers in each session would better enable this problem to be addressed.

Schools, youth clubs, sport clubs etc. are places where children and young people come together and interact with each other and adults, learn about citizenship and act as "citizens" (Howard and Gill, 2000). Focus groups conducted in these settings would allow researchers to work with 'natural' groups (i.e. existing groups where members already knew each other). In other locations groups 
would be formed specifically for this research study. These different types of groups were expected to have different dynamics and inform our understanding of citizenship from different viewpoints. Carrying out fieldwork in a manner which does not intimidate children but rather positions them as experts whose opinions are encouraged is especially important to this study (Balch and Mertens, 1999; Charlesworth and Rodell, 1997).

Focus groups would provide the chance to create an environment conducive to conversation (Harden, 2000), would overcome the researchers' lack of previous contact with the children participating in the study, and would reduce the "distance" between the researchers (adults) and participants (children).

The practical constraints of this study imposed a need to obtain responses from a variety of boys and girls living in different areas in a relatively short space of time. Focus groups were a solution to accessing greater numbers of children in the time available, and would minimise disruption for organisations where the research was to take place.

\section{Design of the focus groups}

The focus groups were designed to be neither so large as to be unmanageable or to inhibit participation by those who wish to contribute, nor so small as to hinder an interactive group dynamic (Merton et al, 1990). Around six participants was planned as the size most conducive to meeting the research objectives, the length of the discussion (one hour maximum), the problems of engaging children for a period of time and the practicalities of access. Two researchers facilitated each group: one leading the discussion, and the other ensuring all issues were covered, as well as being alert to the group dynamic and to non-verbal communication.

\section{Group construction}

Focus group literature argues both in favour of homogeneous groups with similar characteristics, and of diverse groups that give a wider representation of the population and their opinions.

Some researchers argue that focus groups containing same gender participants are more likely to be dominated by specific "ringleaders". Women-only groups are seen as more likely to agree with one another and to defuse group tensions, while men-only groups are viewed as being more likely to disagree with each other (Carli, 1989; Lassiter et al, 1998). However, such research often underplays gendered non-verbal communication and limited conceptions of gendered behaviour have been contested by some researchers. Morrow (1999) for example, maintains that although some of the younger boys in her groups took a longer time to settle down, the boys did not tend to dominate mixed gender groups.

Kitzinger (1995) maintains that in regard to both ethnicity and gender, the participatory and interactive nature of the focus group encourages those who feel too shy or inhibited to discuss their opinions. Madriz (2000) adds that women from settler groups find the multiple lines of communication inherent in the focus group process a safe environment for self-expression.

Age is an important characteristic of this study, which aimed to explore the understandings of children and young people aged between seven and 15. Kennedy et al (2001) argue that focus groups with children and young people should have an age difference of no more than one to two years due to the developmental differences of abstraction, language and ability. The focus group format must be sensitive to the different competencies of children at different ages. For example, younger children may face difficulties understanding questions and concepts, which seem vague to them (Charlesworth and Rodwell, 1997), including the more thematic general questions often used to open up discussion in focus groups. Wherever possible this study worked with same school year or one year difference groups and used simple forms of language and easily understandable questions.

\section{Focus group schedules and research tools}

Citizenship is a complex concept that we decided to explore using the three elements of citizenship identified by Crick (DfEE, 1998): social and moral responsibility, community involvement and political literacy. Whilst recognising that these three elements of citizenship are interconnected and a complete picture of citizenship depends on having all of them, it was decided that covering all three topics in any depth in one group would not be feasible. Two focus group themes were designed: one 
around social and moral responsibility, and the other combining community involvement and political literacy.

The focus groups' schedules were designed around these themes. Age-sensitive activities were created in order to engage children and to prompt discussion acknowledging differences between seven- to 11-year-olds and 11- to 15-year-olds, resulting in four different focus group schedules being devised.

The activities were designed to take account of issues of age, language development and reading/writing skills of children. For example, although some activities use written statements, these are read aloud by the researcher, in order to include those children and young people who may feel uncomfortable about reading in front of a group. Overall, the focus was upon right or wrong; what is fair or not fair; knowledge of rules and laws, and views about other people's behaviour. The activities in the social and moral responsibility group addressed the participants' experience and understanding of rules in different contexts, their ability to shape and negotiate those rules, reasons for compliance, views about right and wrong and understanding of the concept "citizen". The community involvement and political literacy group activities explored their views about their neighbourhood, their activities in their local area, and knowledge and views about politics and their social and legal rights.

The methods were trialled in Pilotstown (not an On Track area) and confirmed that the activities used were generally appropriate and achieved their research aims. When asked for feedback most of the children said that they found the interview "interesting" and "fun". One said: 'it's not like maths where there's got to be a right answer, it's your opinion.'

This is an important point, emphasising that children felt able to voice their own ideas, beliefs and opinions around the various issues related to citizenship

\section{The research project implementation}

The aim of this research was to explore the concepts of citizenship with as many children as possible across the age range seven to 15 years, and to include children and young people from as diverse a range of backgrounds as possible. The research is exploratory and so the precise detail of the sample is not as important as the inclusion of diversity of views. The time frame for this study was short, requiring arrangements to be made at very short notice: all fieldwork had to be completed by the end of March, and contacts could not start until mid January, which effectively gave just nine weeks to make all the arrangements and carry out the fieldwork. With this in mind a pragmatic multi-level approach to sampling was taken.

Selection of the On Track areas was made on the basis of expressed interest in involvement in qualitative work and the characteristics of children in the area as understood from other aspects of the evaluation. Some projects were not able to accommodate the research within the short time frame. In others the need to co-ordinate with other aspects of the evaluation meant that the work was not feasible. The support and assistance of the On Track Co-ordinator and staff were critical to successful access to sites for the fieldwork. They enlisted the assistance of local schools, youth clubs, youth inclusion programme, interventions and community groups to make this study possible.

Access was negotiated directly with the staff on site, who were generally positive because of the support provided by On Track staff. Arrangements were made with them about the children who would participate in the study, the requirements of the researchers, and making the detailed arrangements for the event. Guidance was given to ensure that parents were informed about this work and given the opportunity to say no for their child. Consent from all participants was again sought and confirmed at the time of the group work.

\section{The final sample}

In all, seven On Track project areas took part in this work, generating between two and eight focus groups each. The total number of groups (including the pilot) was 41, which involved 269 children, split between 151 primary age children and 118 secondary age children (this includes two older children who took part in groups). In total 117 girls and 152 boys took part. Gender imbalance was particularly apparent with the older children, mainly because the youth inclusion programme was a 
convenient way of accessing them quickly. The young people in contact with these schemes are predominantly male. The majority of the children who took part were white, but diversity was captured and the sample included nine traveller children, 32 black children, six of Pakistani heritage, and two mixed race. There was wide geographic spread: north and south, urban and rural, London and Wales. Detail of the participation is given in the appendix.

Incentives were offered to encourage participation. Advice was sought from staff about the best way to make these available and an interesting range of responses emerged. In general, the schools that participated felt it would be unfair to reward the few individual children who took part, and requested a donation to the school. The children were usually informed that this had happened, and knew what was purchased. In one primary school which was due to close down the funds were used towards a farewell trip for pupils and teachers. In another primary school the funds were used to purchase Lego sets: this pleased the younger children, but the older ones did comment to us that they felt this was unfair because they did not benefit in any way.

Much of the contact with older children took place in youth clubs and youth inclusion programme schemes, and here it was generally felt that the incentives should go directly to those who took part. In fact it was felt that many would not have taken part without it. Where the "thank you" was given directly to the young person it was in the form of a gift voucher for a local store such as W H Smith where a range of items could be purchased. Again advice was sought from staff about the availability of local stores. One youth club presented an excellent example of participative and collective decision-making about the incentives. That club had a council of members elected by the young people who use the club, and the staff asked them how they would like to take the gifts. The council sought the views of members, and requested a lump sum that could be used towards a day out in the summer for all those who attend the club.

Locations were sometimes not ideal for the purposes of the exercise. It was helpful for the children to be in familiar surroundings, and the assistance of staff was sought to provide a convenient site for the group to take place. Generally, the facilities provided were excellent, and on occasions staff went to considerable trouble to ensure that the groups could run smoothly. For example, one youth club brought in additional staff to ensure that the extra space used would be safe for children and researchers. There were a few occasions though when the arrangements made were not conducive to good discussion. For instance, in one school there was a shortage of space and the group took place in the teachers' lounge where it was disturbed by teachers using the facilities, particularly acute when a teacher commented light-heartedly to the group "I hope you're not telling them bad things about us." In another the requirements had been misunderstood and the school had planned two groups to run concurrently instead of consecutively, but had only one room available to do this. In another, the group was interrupted a short way through as a teacher needed the room for a class: this necessitated the group continuing in the corridor! All in all, however, the children took these problems in their stride and co-operated very well with the researchers in the group.

\section{Participation}

The groups conducted in schools were generally more successful and focused, with the children addressing the issue at hand. This is probably because the structured environment and the routine of school encourages children to sit still, to speak in turn and to raise their hand when wanting to speak. The groups which took place in youth clubs were sometimes more difficult to control, perhaps because the youth club is associated with freedom and fun.

As was to be expected, children were sometimes boisterous in the groups. This was usually manageable with patience and good humour, such as the group of primary school children where two of the group were play fighting and jumping on the table. The researchers had been advised by the teachers that this might happen, and told to ignore the behaviour. The other children in the group ignored them instinctively because they were used to the behaviour. Within a few minutes they stopped, re-joined the group and participated well. Unfortunately there were one or two occasions where the children could not be controlled and alternative action was necessary. In one group a child was harassing other members of the group and would not settle. This was having a disruptive effect on the other pupils, and after ten minutes or so one of the researchers took the child out of the group and to the teacher. It was discovered later that this child had behaviour problems and advice could have been given to help the researchers deal with the situation in advance.

It was unusual for the researchers to experience difficult children in the groups. In fact there is some concern that the children chosen for the groups, particularly by schools, were chosen because they 
would be able to contribute successfully to the group and thus may have been a biased sample. This was exemplified by one teacher who told the researchers "you'll like these kids - they're good". This may have been to be helpful to the researchers, or to give a good impression of the schools. Selfselection by the children was also an important factor: schools usually asked for volunteers to take part in the groups, and teachers selected from the volunteers. The choice of children to participate was thus out of the hands of researchers, and may have created some bias within the sample. However, on balance, we feel that a wide range of views was obtained during this work. There was only one occasion when a child wanted to leave the group after it had started, which was a group in a youth club with an older child who got up and left after about ten minutes of non-involvement. In all other groups the children actively participated.

The feedback from children generally was that they enjoyed the sessions and were interested in the topics and activities. Some commented that it was good to be able to say what they wanted, and even to have a say at all. Most were appreciative of the incentives and refreshments provided, though some felt that the change from the normal lesson routine was incentive enough. One particular problem with providing the incentives to individuals is that this could have led to some unfairness. As a consequence the groups were sometimes made a little larger than ideal rather than exclude one or two volunteers. This occasionally had a detrimental effect on the quality of the discussion, for example there was one group with nine participants, and this really was too large for good discussion. The optimum size would be four to six.

The participants and the staff were very interested in this piece of work and keen to know what would be happening to the results. Many requested some feedback and to see the final report. It is planned to produce summary reports for both projects and participants when this report has been accepted and approved.

\section{Facilitating discussion}

The success of the groups was dependent upon the co-operation of the children and their willingness to engage in discussion about the issues of concern to this study. This was facilitated by the construction of the groups, the activities designed to trigger the discussion, and the skills of the facilitators of the groups. The activities were designed to be age appropriate for the particular group of children, and usually worked well as planned. However, the researchers learned to adapt the exercises to meet the needs of the group, allowing them to be more or less active and building on ideas which they introduced. This is the essence of good qualitative work, that it enables the participants to construct the detail of the dialogue under the guidance of the skilled researcher who has clear objectives in mind. Facilitators of the groups encouraged participation by all members of the group, repeating points often to check that they had understood what the children were saying, and using probing techniques to develop fruitful avenues of discussion.

That is not to say that everything was perfect. The pace of this study was fast, often requiring researchers to run four consecutive groups in a day. This was tiring and did not allow adequate time for reflection and note writing between groups. All groups were audio recorded for transcription, but some proved problematic: the conditions were sometimes not conducive to good recording, perhaps because there was background noise, the acoustics in the room were not good, or children were speaking together.

\section{The Activities}

Social and Moral Responsibility incorporated three sections. The aim was to explore children's perceptions of rules, their understandings of right and wrong, and what involvement they have in the making of decisions which affect them. Their task was to generate a list of school rules and say whether each was good or bad and why, before choosing one or two to discuss in some depth. The second component was a vignette, where the children were asked what they would do if they were out with a friend who steals a bag of crisps/CD/money, how they thought others would feel, and how they would feel if they were the victim. The third exercise was to take one school rule and one home rule that they did not like and discuss where the rules came from, the reasons for them, and how they would go about changing them. At the very end of this session participants were asked if they knew what "citizen" was. The exercises were much the same for both age groups, but with some flexibility in exactly how they were implemented. 
Community Involvement and Political Literacy had two activities: one for each section. The community involvement activity asked the children to discuss their local area and the people who lived there, highlighting the good and bad things about it, and also asked about the activities that they were involved with and who they helped. The political literacy exercise presented the children with a range of statements on cards (e.g. I usually stick to the rules, I trust the police, I watch the news on TV), and asked them for the group consensus on whether they agreed with it or not. The exercises were basically the same for both age groups, but with more statements for the older group in the political literacy exercise.

The activity which most often worked well was the political literacy exercise where children were asked to choose cards with statements on them and indicate whether they agreed, disagreed or couldn't decide. This was a group decision and prompted interesting (though sometimes boisterous) discussions among the children to achieve agreement. The vignettes in the social and moral responsibility section also worked well with children enjoying the story and imaginary scenario. Children became more easily bored with exercises with flipcharts and discussion, but still generally participated well. This was because the exercises were not felt to be patronising, and researchers worked hard to ensure that the children knew that their views were important and would be listened to. They carried out the fieldwork with an open mind, accepted what the children and young people said, questioning only for clarification and expansion, and focused on the research objectives. In effect, they worked with the children and young people to give them the opportunity to have their say.

\section{Analysis}

All focus groups were tape recorded, with the permission of participants, and notes of proceedings and key points kept by the group facilitators. Tapes were reviewed soon after to check the quality of recording. Problems occurred with two tapes: one where the pick up of extraneous noises meant much of the discussion could not be heard, and the other where there had been a problem with the machine. More detailed retrospective notes were made of these sessions by the facilitators, but direct quotes were not possible.

Satisfactory tapes were passed for transcribing, and all but three were successfully transcribed for detailed analysis. Unfortunately these latter three could not be transcribed within the timescale available for this piece of work, and therefore they were included in the analysis by listening to the tapes themselves. The five focus groups where no transcript was available were spread across four different locations.

A manual iterative thematic analysis of the transcripts and tapes was undertaken to identify the key themes emerging from the work. This was assisted by the use of word processor package search and cut and paste facilities. The two primary researchers ${ }^{2}$ involved in data collection initially worked independently to identify the range of points emerging from discussions within the three aspects of citizenship that were the focus of this work: social and moral responsibility; community involvement; and political literacy. Each aspect was addressed within every transcript, even where it was not the direct theme of the focus group as substantial overlap in issues emerged during the children's discussions. Emerging themes were discussed with the principal investigator, ideas refined, linked to the literature and checked with the data, leading to full detailed reports on the analysis prepared for each aspect of citizenship. This cycle occurred several times and the final detailed reports were further analysed and refined to produce the key themes presented in this report to represent the voices of the children and young people that took part in the work.

\footnotetext{
${ }^{2}$ Sarah Cooper and Insan Fathallah-Caillau
} 


\title{
4. The voices of the children and young people
}

\author{
Social and moral responsibility
}

Rules

Children and young people had no problem identifying rules at school or at home. Often the rules were quite formal, but sometimes what they reported were things that they were told they must and must not do by teachers or family.

The children and young people demonstrated a strong awareness of why rules are necessary, and generally felt that most of the rules they have to comply with are good and necessary, even though they are experienced as restrictive. They appreciate that the rules are not necessarily the same for everyone, and can accept this, but are not happy to see or experience rules being applied discriminately or unfairly. There are also rules, which they perceive as "silly" and these they generally feel to be unfair rules, which can justifiably be ignored.

\section{School rules}

The rules presented in relation to schools were very similar in all areas: for example no bullying, no wearing trainers, no mobile phones, don't back chat the teachers. Most pupils said that their school rules were displayed in schools and could say where these could be found. They were also aware of what happened if they did not comply with these rules, which was usually punishment of some kind.

The children were aware of the need for rules, and the reasons behind them. In fact they were able to articulate a wide range of reasons for many of the rules:

i) to teach children: "it's like when you grow up, you don't want to be some smug with no manners or anything ..." (Pilotstown primary school boy) ${ }^{3}$

ii) for the benefit of the school: "All of them [rules] are important to create a good school" (Yellowtown primary school boy)

iii) safety: "we've got little kids walking around school and there's been a few accidents when people are running and knocking them over" (Greenstown ten- to 11-year-old boy)

iv) appearance: "it's good cos people could get it on their clothes" (Whitetown primary school boy, talking about a no chewing rule)

v) concern for others: "if you don't respect other people's property then ... it's cost them money to buy new coats all the time" (Yellowtown primary school boy)

vi) to avoid arguments: "if you damage someone else's they will probably just damage yours and you will start having a big argument about it" (Yellowtown primary school boy)

vii) to give a sense of identity: "because then people can tell who you are and where you come from" (Yellowtown primary school boy talking about wearing a school uniform)

viii) for future benefit: "I think they've got a reason for giving us homework because they're trying to get us to achieve the best that we can" (Yellowtown ten-year-old girl)

Thinking about the future was important to many children, and was given as a reasonable justification for many rules, for example listening to the teacher (so that you learn) and no copying because:

...if you just copy it someone else is ... you don't learn it, do you? (Greenstown nine- to tenyear-old).

If you don't work hard then you won't get a good education when you're older (Greenstown nine- to ten-year-old).

Children demonstrated that they could understand contradictions in relation to some rules. For example, in relation to the ban on trainers at school, they understood that on the basis of appearance and smartness shoes were better for the school reputation, especially as part of the uniform. However, at the same time they felt that trainers were more comfortable to wear and often safer. This was a rule that older children were less likely to respect, so for example one older boy in Metstown

${ }^{3}$ Fictitious names have been given to all the areas participating in the study. 
suggested the reason for the rule was teachers "wanting to be awkward". Some rules they felt were unfairly applied in all circumstances, for example not being able to wear a hat in winter when it was cold.

School uniform was frequently raised in discussion, and again pupils could rehearse the reasons for having one but still be unhappy about wearing it, again having cogent counter arguments for not wearing a uniform, such as this young girl:

We feel more comfortable in our own clothes and we reckon that it's not fair. We should be allowed to wear what we want and not what other people want us to wear. It also itches. And, that... and that... and that's stops you from concentrating. I would say is... a little badge to say your school is enough (Pinkstown ten-year-old).

Other children reflected on the apparent unfairness of different rules for teachers in this respect:

We're required to wear our black school uniform everyday...black... black... black...but the teachers are allowed to wear whatever colour they want and anything they like...they also wear trainers to school, but we aren't (Pinkstown 12- to 13-year-old girl).

The rule about no chewing or no sweets was common to many schools, and prompted many interesting discussions. It presented a good example of how a rule could be cogently rationalised even though the children did not like it. Primary school children in Metstown for example had a long discussion about not being able to bring sweets into school. The children did not agree with this rule but at the same time could think of many reasons for its enforcement, such as keeping their uniform clean, so they do not choke, so that they do not upset other pupils that cannot afford to have sweets and so that they are not distracted in lessons. The children could also suggest counter arguments: for being allowed to chew in class:

...like if you're chewing while you're doing your work you don't necessarily have to start talking to somebody (Pilotstown primary school boy).

Children could prioritise rules into those which were more necessary and those which were less so. For example the older boys in Metstown felt that rules such as no trainers, no hats and no jewellery were not needed, whereas others, such as no smoking and no alcohol, were. They frequently flouted the rules they felt unnecessary, for instance by wearing trainers for school, and suggested that they were likely to smoke and drink but probably not at school.

There were some rules which children could see no reason for, and these were described as "silly". The sorts of rules, which fell into this category are "tuck your shirt in" and "put your coat on the back of your chair". They were more inclined to flout these rules.

There were some examples of children being asked to do things they were very unhappy about. The Yellowtown primary school children had the following discussion about drinking their milk:

Girl 1: I don't see why we should drink our warm milk.

Boy 1: I don't think it's fair ... like we have to drink our milk after playtime ...

Girl 1: They like us to have our milk, but like the milk is off because it was in the sun for long

Boy 2: It should go in the fridge ...

Boy 1: When the teacher says that I should have my milk, I say no.

Fairness

Children often raised the point that apparently different standards were expected of themselves and of teachers, and felt this particularly unfair. It was felt that teachers had fewer rules to adhere to, and some rules that were enforced on children were not followed by the teachers. A classic example that was discussed in a number of areas (in particular Metstown and Whitetown) was the rule "no shouting". Children described how teachers would often shout at the children but would reprimand the children when they raised their voices to each other or to the teacher. Indeed while one of the focus group discussions was underway in the primary school in Metstown, there was a teacher in the background shouting very loudly at the children in her class. The children commented on the "no shouting" rule saying that sometimes it was necessary to shout back at the teachers because "you have to give them your opinion" and "teachers do not listen to them". 
Teachers not listening was a common complaint from the children and young people. The following example also reflects how apparently trivial issues for teachers can be very important for children. The teacher had an incentive scheme to encourage children, but did not attend to the important detail:

Every time we do something good, we get a point, and then we get a chocolate with nuts or coconuts. But, many of us are allergic to nuts, but our teacher never changes that chocolate...She promised to change it last year, but she didn't. (Greenstown ten- to 11-yearold boy)

The older boys in Metstown felt that the "no smoking" rule was a good rule but then "why do teachers smoke?" Some agreed that the teachers should not smoke, as they should be role models for the young children - the children appreciate the value of pro-social modelling but apparently the teachers in this school didn't. After further discussion it became clear that the rule was more specific, as smoking in the school buildings was not allowed by anyone. They said that teachers smoke in the building and they felt this to be very unfair. It suggests that these teachers perhaps take care that other adults do not see them breaking this rule but that they do not worry about children witnessing this behaviour - suggesting the pupils are perceived as "invisible" or unimportant.

Another example of not being listened to about an important issue in school came from Pilotstown:

I want someone to check our complaints... I found a piece of metal in my fishcake once. I went to the... the dinner lady and said this is in my fishcake, she opened it and she said that hasn't come from this kitchen so... yes, that's cos it wasn't there before...And the little thing was missing off the metal thing that she whips it with (Pilotstown ten- to 11-year-old boy).

This example highlights a very important issue in relation to citizenship, that of individuals knowing their rights as well as their responsibilities and having the means to resolve issues about them. Being listened to and treated with respect is the right of a citizen, and public institutions have a responsibility to try to ensure that this happens. This finding confirms the view of writers such as Gilligan (2000) who have commented on the importance of attending to the apparently unimportant detail:

Caregivers, teachers and social workers should remember that the detail of what they do with children counts. ... All of these little things may foster in a child the vital senses of belonging, of mattering, of counting. ( $\mathrm{p} 45$, emphasis in original)

Home rules

Children are also quick to list rules at home and how these are enforced. Their safety is often presented as the reason for rules at home.

I'm not allowed in the park ... because there are flashers and druggies around (Yellowtown primary school girl).

I think some of my house rules are fair... Like, if you make your own decision and you say I want to stay out to play at 11 o'clock, then people who are strangers, they might come and kidnap you or something (Orangetown, nine- to ten-year-old boy).

I think some rules protect you ... like not to stay up late outside because there are bad teenagers around who would harass us (Yellowtown ten- to 11-year-old boy).

But not all are welcomed:

There's too many rules at home... It is turning into school and a prison (Bluetown 11- to 15year-old).

When discussing rules at home some children explained about different rules for siblings, generally with the view that this was unfair, and usually in relation to younger or older brothers and sisters being able to do things which they weren't allowed to do. For instance not being able to retaliate when a younger sibling "kicked them in the shins" (Yellowtown), or taking a fair share of jobs around the home: 
... me and my older sister share a bedroom ... when it comes to tidying up erm my sister makes most of the mess and she just watches TV and I don't get paid pocket money but she does for doing nothing ... (Greenstown primary school girl).

This discussion between primary school boys in Greenstown demonstrates the extent of resentment about siblings.

Boy 1: I talked to my mum and she just said 'Well they're too young to do chores yet' or something

Boy 2: My brother's 17 ... and I like do all the chores. He doesn't do one thing even though he's grown up and I'm like doing all the chores still. Like I go to bed at nine or ten or something. My brother goes to bed like 12. My mum says that "your brother is grown up, he can stay later than you".

Boy 3: ... but the point is, it's unfair for me because I have to do all the work and like when I'm playing the PC or something, my brother comes, pushes me out of the chair saying 'I'm playing it now' and really like annoys me.

\section{Obeying rules}

Children and young people overall accept the need for rules, but their reasoning about whether to comply with rules is clearly sophisticated and mediated by a variety of issues.

a) Compliance depends on the situation

Children rarely described their compliance with rules as always one thing or the other, but often referred to the need to consider the particular situation when making the decision. For instance, "no fighting" was a rule which was often described as being applied to both school and home, and children articulated the differences well. They described fighting with a brother or sister at home as different from fighting with someone at school.

They also described differences between boys and girls in their understandings of fighting and its role:

It's quite a quick way to sort out a problem though cos women they have to go through all this "I'm sorry" and stuff but sometimes... in our school one lad you just have to ... you have a fight and then you are mates after the fight cos you've sorted it out. That's how it normally works (Pilotstown primary school boy).

A group of ten- to 11-year-olds in Yellowtown would have agreed with this view, suggesting that boys fight whereas girls argue, although girls may "slap" one another. They also discussed differences between the bullying of boys and girls. In their opinion, boys bully boys in school, whereas girls bully girls out of school

\section{b) Complying to obtain a reward}

The notion of reward for complying with rules was raised by a variety of groups. This is a technique used by adults in both the school and home environment as a way of persuading children to obey the rules. In Greenstown for instance, the primary school children described a "Golden Book" and a "Bad Book" accompanied by a point system and chocolate as a prize for doing homework. A primary school in Orangetown had a similar system, which was described as "Gold Tickets" and "Red Tickets" for obeying and not obeying rules. In a discussion with older boys in Metstown about whether to obey a rule the response was "it depends if you get something back". Children demonstrate an understanding of the value of reciprocity:

If I do things for my mother like tidy my room, turn off the alarm clock and turn on the heating in the morning... and I wake her up...she lets me stay up late and watch TV (Pilotstown tento 11-year-old).

And of course parents frequently reward good behaviour at home with pocket money.

c) Complying to avoid punishment 
Children usually said that they obeyed rules because they agreed with them and thought they were good rules, but sometimes they did admit it was to avoid getting into trouble.

...you could get into trouble for ruining other people's property (Yellowtown primary school girl).

Children are usually clear about the possible consequences of not complying with rules, and the different severities of punishment. They accept that the severity of punishment varies both with the nature of the rule that is involved and the number of times they have broken the rule.

...no swearing in our school is as strict as anything. If you get caught swearing you do like an hour's detention or something like that (Pilotstown primary school boy).

d) Complying to avoid feeling bad

Fear of the consequences was not related only to concerns about external factors, as many children suggested that they would feel guilty about disobeying some rules. Some nine- to ten-year-olds in Yellowtown said 'It doesn't feel good to break a rule', and another group in the same school said: "inside you feel bad cos you know you shouldn't have done it".

e) Breaking the rules can be fun

Children described some situations in which they felt it was worth taking the risk and breaking a rule, for example in relation to not fighting two primary school boys in Pilotstown said:

Boy 1: No fighting's good.

Boy 2: It's a good rule but everybody enjoys the fight and stands around and starts cheering.

f) Breaking rules can happen unintentionally

Some children described how rules can be broken without meaning to. For example, two boys in Pilotstown described how it was possible to bully someone without realising that's what you were doing.

Boy 1: ...sometimes you can call somebody something like a name or something and to you it doesn't mean anything but to someone else ...

Boy 2: To them it did

Boy 1: Yes. ... or you're just having a joke. Some people just can't take jokes and they just, like, take it as you are laughing at them

Boy 2: And bullying them.

In Yellowtown a group of ten- to 11-year-old boys described how following an instruction from a teacher had resulted in a rule being broken:

If we're doing a job for a teacher like take this to the other end of school. But when your class is ready to do work and they're working and you're not back there yet and they've already started the session, how are you meant to get there on time? Cos if you get there walking the teacher says, "Why are you late?" And she says something like you have to miss 15 minutes of your break time.

g) Breaking rules is sometimes necessary

Several groups of children suggested that it was sometimes necessary to break rules. Peer pressure was one reason as illustrated by an example from a ten- to11-year-old boy in Greenstown:

... this boy, ... he tried to climb over there ... and he was asking me to [do it] as well and stuff and...And I actually done something, well it was bad, I sweared! I said a bad word while we were in the streets and [he] was threatening me, blackmailing me saying, "If you don't climb over the fence with me, l'll tell, I will tell your mum what you've done". So I basically had to do it.

Peer pressure was apparent in one group of older boys in Metstown. It was evident that some of the group felt uncomfortable about saying things they felt the rest of the group would not approve of, and this was particularly so where the general view seemed to be that it was good to break the rules, and 
good to be bad. The researchers, and a youth worker present, all felt that there were some members of the group that would have liked to put an alternative view forward but could not. Nor could the researchers find a way of enabling them to say so in that group.

A reason put forward for breaking the no fighting rule was self defence and to preserve their selfesteem:

Because they say if someone hits you, you've got to tell the teacher. You can't just let someone hit you because they're going to keep doing that and then everyone is going to start doing that, so you have to start building up a reputation and start knocking men's [inaudible] out when they start on you (Metstown, older teenage male).

Some children suggested that they were not listened to by their teachers unless they shouted, and this justified the breaking of the rule:

It is necessary to shout at times as the teachers do not listen (Metstown, older teenage male).

h) Some rules are not enforced

Children's compliance with the rules is often affected by their view of the consequences of not complying. Where they feel a rule is not properly enforced they are happy not to comply. Older boys in Metstown described how being caught in contravention of the not smoking rule usually resulted in being told to "put it out", which did not deter them from smoking.

Children are affected by responses they have witnessed to other children's non-compliance, and the extent to which other children comply, particularly among the older children. For instance in Whitetown:

Interviewer: Tuck your shirt in is it?
Boy 13/14: No-one ever does it.

Hardly anyone takes any notice of it, it doesn't matter if you smoke under age, or drink under age either (Pinkstown 15-year-old girl).

i) Authority and power

Children accept that certain adults have the authority and power to make and enforce rules. The list of adults they perceive as having this power is long, and includes teachers, the head teacher, parents, school governors, the school council, the Government, and the police. Head teachers in particular are felt to have substantial authority, and sometimes that it all that is necessary as a reasoning for a rule:

our head teacher said that we're not allowed to wear trainers (Metstown seven- to nine-yearold girl).

The head teacher is understood to make the school rules, and these were generally felt to be rules that should be obeyed. However, there is also the added dimension of the children's views about the individual making and enforcing the rule, particularly in school:

Depends on whether or not you respect them, or something like that (Pilotstown primary school boy).

Right and wrong

Kohlberg (1983) suggests that children of different ages will have different levels of understanding, and presents stages of moral development:

(1) it is wrong because it is imposed by a figure of authority

(2) it is wrong because you wouldn't like it to happen to yourself

(3) it is intrinsically wrong

(4) it could damage society

(5) it violates an important principle.

The results from this study suggest that the reality of children's understanding is more complex than Kohlberg suggests, and although they present ideas related to each of these stages, this is not in any 
linearly progressive way. They can have some or all of these understandings at the same time, and indeed they often all emerged within one focus group. The children additionally presented arguments concerning effects on other people. As well as their age and level of maturity, social forces such as belonging to different communities, cultural and racial diversity and gender differences will influence children's moral thinking and development.

Children in this study had no trouble identifying with the scenario presented to them about a friend taking a bag of crisps in a shop. They overwhelmingly knew that this was wrong, and usually knew that the friend was breaking the law. The range of responses to this scenario reveals the children's understandings of the complexity of issues of right and wrong, and tends to contradict Kohlberg's thesis. Critically they have understanding of the importance of context.

Knowledge of the law

Children become much clearer about the possible consequences of breaking the law as they get older. For instance, when discussing the stealing a bag of crisps scenario in Greenstown with primary school children:

Interviewer: If the police found out what do you think would happen?

Boy aged ten to 11: They'd get a warning.

And in Whitetown with 13- to 14-year-olds:

Boy 1: They won't take you to court over that.

Boy 2: Not for a 30p packet of crisps.

They are also aware that the punishment can vary with age. Again Greenstown ten- to 11-year-old primary school boys:

Boy 1: Young Offenders Institute.

Boy 2: All depends what age you are ...you have to be over 12 to actually get in.

Justify the action

Although they understood that stealing was generally wrong, children did present justifications for their friend's action which would make it acceptable:

...but it could have been somebody who was blind a bit and like haven't got a good eyesight and could not see where to pay (Pilotstown ten-year-old boy).

Other reasons offered included:

they were hungry

Like drugs or stuff like that. Cos some people steal who need drugs. I don't think they'll steal a packet of crisps for it but ... (Pilotstown, ten- to 11-year-old boy).

Most of the reasons suggested were related to the perpetrator not having any money, for example the Metstown teenage boys suggested:

...what we said was it's wrong. Other people, l'm not being general, but you might think yeah, there's always an extra choice but certain people might think there's no other way. ... They ain't got no money have they.

Many children were concerned to understand why their friend had stolen:

I'd ask why he did it cos it could be anything, could be that he didn't have enough money (Pilotstown 11- to 12-year-old girl).

...tell them to think about what they've done and think if they've done the right thing (Metstown seven- to nine-year-old boy). 
I wouldn't get the police involved just yet, I would just go up to the person and say what you doing but if they started using foul language and something l'd go and phone the police (Greenstown nine- to ten-year-old).

Talking to the person involved was most often mentioned by primary school children, but it was at times mentioned by secondary age children too.

It could be fun

Although most children thought stealing the bag of crisps was wrong, there were teenagers who suggested that a bag of crisps wasn't really important, and even that it could be fun. For instance a comment from a 13- to 14-year-old boy in Whitetown was "l'd say good for you".

A minority of children felt that stealing a bag of crisps was not a problem because it was not worth very much and would not seriously affect the shopkeeper, and some went so far as to justify the behaviour by suggesting "shopkeepers overcharge everybody anyway" (Metstown teenage boy). Other members of the group disagreed with this.

\section{Disapproving}

Many children, however, disapproved of their friend in the imaginary scenario. For instance, the eightto ten-year-olds in Pilotstown referred to being ashamed and not being able to trust their friends in future. Nine- to ten-year-olds in Greenstown said they would be "angry", "upset", "shocked" in the situation, a ten- to 11-year-old boy stated "I would feel that he isn't actually my friend". A 13- to14year-old boy in Whitetown was similarly disapproving, saying that the behaviour was "disgraceful, thieving".

\section{Effect on others}

Some children demonstrated awareness that people other than the shopkeeper were also affected by such actions, for example the ten- to 11-year-old in Greenstown:

like Kylie Minogue sung and made that album, someone buys, all the money goes to Kylie Minogue, the singer. So if you steal one, that's a bit unfair for her.

Another suggestion was that the person was setting a bad example to younger children:

because you have to pay for everything that you buy and some little kids might go into the shop and steal (Metstown primary school girl).

\section{Empathy for victim}

When discussing why stealing was wrong, children often showed empathy for the victim and were concerned for the effect on others. Many children demonstrated an appreciation of the shopkeeper's point of view, suggesting that the shopkeeper would feel "sad", "angry", "shocked", "suspicious".

It's not fair on the shopkeeper because he buys, he has to buy all the food that he gets and then it's just like giving it away (Pilotstown eight- to ten-year-old).

...that shopkeeper he's just lost some money hasn't he (Pilotstown eight- to ten-year-old).

...the shopkeeper needs that money (Greenstown ten- to 11-year-old).

Because he's paying for stuff that people are just robbing off him so he's wasting money (Whitetown 13- to14-year-old boy).

Restorative justice

There were examples of restorative thinking evident from a range of the responses of children. Some suggested they would make reparation on behalf of their friends, for example, 
I'd feel quite upset and l'd go and get the thingy they stole back and put it back in the shop (Greenstown nine- to ten-year-old girl).

If my friend robbed something from the shop I would go in the shop and give him [shopkeeper] the money and pay for it (Yellowtown eight-year-old girl).

But most suggested they would try to persuade their friend to take restorative action:

I'd tell him to give him the money (Pilotstown 11- to 12-year-old girl).

If I seen him stealing it I would go over to them and tell them to go back into the shop and give the crisps back (Yellowtown eight-year-old boy).

You can tell the shopkeeper what happened and say that they'll pay tomorrow and you have to get them, you have to get them to pay (Metstown seven- to nine-year-old girl).

\section{Telling someone}

Many children said that they would tell someone in authority what their friend had done. For example, Greenstown nine- to ten-year-olds suggested:

Even though he was my friend, I'll just go and tell the shopkeeper.

I wouldn't tell the shopkeeper but l'd tell my mum and dad ...

l'd go and tell the shopkeeper to ring the police ...

Whitetown 13- to14-year-old boys opted for telling their parents, whereas Pilotstown eight- to tenyear-olds discussed a range of people including the shopkeeper, the police and the perpetrator's mum.

Although there was a great deal of agreement that people in authority should be informed when a crime is committed by a friend, there was also some anxiety involved in deciding whether they actually would tell. Metstown seven- to nine-year-olds were worried about possible reprisals if they told someone.

Girl: Yeah but don't you think that they're going to come after you after, if you tell of them..

Boy: they'll be cross

Child: You want to tell but you can't because you might get into trouble.

Child: trouble by the person, or their mum, or your mum might say that was wrong...

Some children were concerned about loyalty to their friend:

Cos they're like my mates and I won't grass on them. They wouldn't be my mate no more (Pilotstown 8- to10-year-old).

Because he's your friend and if you been friends for a long time, you wouldn't wanna break friends with him (Yellowtown nine- to ten-year-old).

Though loyalty was determined by the closeness of the friendship according to these 11- to 12-yearolds in Pilotstown:

Girl: Depends on who it was. And how close a friend they were.

Boy: It's like he said earlier, it depends on how close a friend it is. If it isn't your friend, then you can just tell.

Taking it personally

When asked how they would feel if they were the victim of the stealing, the children's responses were less sympathetic. Loss of trust and feeling hurt and betrayed was common in the descriptions where 
the children themselves were the victim of their friends' behaviour. An 11- to 12-year-old boy in Pilotstown said "don't leave any valuables anywhere".

Generally there was less understanding towards the perpetrator by all children and young people when they personally were the victim of the incident. The impression given was that they would view the incident more seriously if they were the victim. Many suggested some form of direct personal action if they were the victim.

Most said that they would be upset or shocked, though not many went so far as the girl in Metstown (seven- to nine-year-old) who said that she would be "devastated". Many talked about obtaining compensation in some way, such as:

Ask them to borrow the same amount as they stole from you and pretend to forget about it. (Metstown seven- to nine-year-old girl).

Other suggestions included stealing the item back using different methods and generally being aggressive towards the perpetrator, by for example, "tripping them up". Older children often had much stronger views, such as Pilotstown 11- to 12-year-olds:

Girl: l'd shoot them.

Boy: l'd tell the cops me straight away.

Boy: I wouldn't think twice about going to the cops about him if he nicked something off me

and the Whitetown 13- to14-year-old boy who said "beat them up, take their money". Older teenagers also inclined towards retribution, suggesting that they would take direct action themselves rather than bring in someone else.

It's just wrong

Although the children and young people could discuss and rationalise behaviour such as stealing, there was also a firm belief in something being "just wrong" and although you might be able to explain the reasons for someone's behaviour, that would not excuse or justify it. They believe there are some things you just do not do - they have an implicit moral code.

Cos you're supposed to buy it ...it's breaking the law cos it's theft. Doesn't matter if it's free, you're still thieving something aren't you?

is how 13- to 14-year-old boys in Whitetown explained that stealing was wrong. A view affirmed by Yellowtown eight- to nine-year-olds and ten- to 12-year-old boys in Greenstown, who were quite frustrated that the researcher did not seem to understand them.

Interviewer: So why do you think it's bad to actually take something without paying for it? Boy: Because it's wrong.

Interviewer: But why is it wrong? Why?

Boy: Because it's not our property. We shouldn't take...

The belief that offending is intrinsically wrong has been identified as a key factor among children who resist involvement in offending (Jamison et al, 1999).

But some things are more wrong than others

Children generally thought that stealing more valuable items was more wrong than stealing things of lesser value. They said that stealing a more expensive item from a shop such as a CD would be "totally worse" than stealing a less expensive item like a packet of crisps. This was something discussed in many of the groups.

It would be worse if you take something for like a lot of money for $£ 100$ than something for 50p (Metstown seven- to nine-year-old).

And one primary school child in Yellowtown said much the same, but from the perspective of the shopkeeper: "if it was 10p I wouldn't mind, but if they were dearer I would". 
The children demonstrated some understanding of the complexity associated with moral values, as in the following extract taken from a group discussion of 13 and 14-year-old boys in Whitetown.

Interviewer: Let's go back to the example of taking a CD. What do you think about that? Is it the same as taking crisps, better or worse?

Child: Worse than taking crisps.

Interviewer: So if it's more valuable than a packet of crisps then it's more wrong to do it?

Child: Yes.

Child: No.

Child: No.

Child: Not supposed to do it anyway.

Interviewer: So first of all you said it was worse because it was harmful but then you said it wasn't as wrong as taking a packet of crisps. Do you mean it's the same kind of thing?

Child: No.

Child: Yes.

Child: Yes.

Child: Still robbing stuff.

When asked to reflect and articulate about right and wrong, and degrees of "wrongness", the children can clearly understand that the value of the article is important in relation to theft, but generally hold the view that stealing of any kind is wrong:

Cos whatever you're nicking it's taking something from somebody else isn't it? It doesn't matter how much you nick you are still taking from somebody (Pilotstown 11- to 12-year-old boy).

And that really isn't the right thing to do anyway ... if you want ..something you'd have to pay for it not like go and steal it (Pinkstown seven- to nine-year-old).

There was some variation by age: for example, the older boys (14- to19-year-olds) in Metstown felt that stealing a CD was still a minor offence of little consequence. Indeed when the subject was put to them the group laughed. However, they continued the conversation and introduced the idea of stealing a CD player, which was thought to be more wrong:

Boy 1: That's too big alright, that's criminal.

Boy 2: I wouldn't allow it.

\section{Making and changing rules}

The third exercise in the social and moral responsibility groups was designed to explore children's role in the making and changing of rules and their understandings about how things happened. The group was asked to make a joint choice of one rule at school and one rule at home that they did not like, and the discussion focused on how they might go about changing those rules.

The children are aware of the people who make decisions and have some control over them in many spheres in their life (including God, the government, "that fella who's boss of all the schools", and teachers and parents). They also demonstrate awareness of different systems which impinge on their lives, such as the law, education and politics, and various ways in which they might go about influencing them. The options mentioned included sending a petition to government or the council, voting to change the people that are in charge, and writing letters to the council.

The children generally described that they would talk to parents or teachers as the first step, though the overall impression is that the children thought that they have a limited say in decision-making both in school and at home. The more remote the source of authority the less able they felt to be able to influence it:

It's easier to talk to your parents than it is to get in touch with the Government cos there's loads. You can't actually do it face to face can you? You've got to do it in letters and stuff and there's nothing saying that they've actually got to read that letter so you never know if they're actually taking it seriously (Pilotstown ten- to 11-year-old boy).

There is a sense of powerlessness in relation to their ability to initiate and achieve change. When they report involvement in decision-making it is usually apparent that adults initiate it. Perhaps because of 
this feeling of powerlessness, or because they have not learned any other way, children report two commonly used tactics for influencing a situation. The first was conflictual: to refuse to do something and risk the angry consequences. The second was avoidance: to find a way of not doing something they did not like, but also to evade any punishment for it. These tactics were most often reported in relation to home rules:

Girl 1: You can just make them feel upset.

Girl 2: Yes...

Boy 1:You don't have to follow it do you? (Pilotstown 11- to 12-year-olds)

The researchers sometimes felt the force of the children's frustrations directly, where they were probing to gain a better understanding of issues the response would be exasperation at the researchers' apparent inability to understand what was blindingly obvious to the children.

\section{School rules}

Children distinguished between classroom rules and school rules in this discussion, saying that they had some influence in respect of classroom rules, but no influence at all with school rules. One child described the difference:

The rules that are for the whole entire school you have to obey. Only if you haven't got rules in your classroom, you still have to obey the ones that go round the whole school (Metstown seven- to nine-year-old).

Children describe "telling the teacher" if they were unhappy with a rule, but their ability to change things is generally very limited. Many, like these ten- to 11-year-olds in Greenstown, are hesitant even to raise their concerns:

Boy: No. We're like too scared.

Interviewer: What, at home or school?

Child: School. Cos if we like tell the teacher to do something they just give you the evil eye and say no.

The children generated some understanding of the consensual nature of rule making and changing. For instance, Metstown primary school children talked about people needing to talk about rules and come to an agreement. The felt that "everyone in the school has got to agree with it".

Older boys in Metstown appeared to be particularly frustrated by the system of rules, suggesting that "they are just made up" and that "you can't change them, how do you change them?" One older boy made the comment, "they don't listen to me, l'd rather my mum go down there", implying that parents had more authority with the school. Not being listened to was a common source of frustration, as illustrated by this discussion among seven- to eight-year-old girls in Pinkstown:

Girl: Some of our teachers always make mistakes, she thinks we do something and like the other person did it and we get into trouble for it.

Interviewer: But don't you explain to them?

Girl: We explain to them but they don't listen.

\section{School Councils}

Some children talked about the opportunities which existed in their schools to be part of the rulemaking process. A Pilotstown primary school had a system of class representatives, which was described by one girl as:

When there's this girl comes in ... and she helps people and she picks a group of people to come out and sometimes she just picks my friend to come out and she ask us what bad things have happened to you and what you'd like to do in your schools... what new things you would like and she jots everything down and...most people say change some of the rules.

Greenstown primary school children talked about their school council very positively, reporting how it meets once a week to "help the school environment get better". Two children from each class sit on this innovative council each week, either chosen by the teacher or voted in by the class. The children 
enjoyed being the representative because they had treats for taking part and importantly, the children valued being able to have an input.

Child: You get to make your own decisions.

Interviewer: Right, okay. You think that's important. And the council gives you a chance?

Child: They make sure we make the right decisions.

Unsurprisingly, it does seem that the teachers retain overall control, but the positive tone of the above quote illustrates that this is not experienced as controlling. The children really felt they had a proper input to the decisions of the school council, giving many examples of how it had worked in practice.

[head teacher name] who organised it, she's said it's not up to her, you lot have to talk about it to each other so you decide altogether.

Unfortunately not all the school councils were reported so positively. The evaluation of experimental projects that involve children and young people highlight the dangers of tokenism (e.g. Bickmore, 2001). Our findings mirror those of Morrow (2001), who reported that the children in her study perceived a "reluctance on the part of the teachers to take suggestions seriously" (p36). Below are two quotes from Yellowtown and Pinkstown, where the children clearly feel the school councils are ineffective:

There is two representatives for each form and then there is two year ones, I am one of the form ones and they go and tell the teachers, and they go to a council and give the suggestions and everything, the teacher thinks, "right, we'll go away and think about it", and then we never hear anything about it again (Pinkstown 14- to 15-year-old girl).

Interviewer: Do you feel you have a say in your school?

Girl 1: $\quad$ We have a school council, but no one wants to be part of it cos nothing gets

done...

Girl 2: $\quad$ Remember when we asked them for another vending machine and how they've taken the only vending machine we had...

Interviewer: Why did they do that?

Girl 1: $\quad I$ don't know... (Yellowtown ten- to 11-year-olds)

Also in the Metstown primary school children described the "memo tree" where they could suggest new rules. The teacher and head teacher have the power to decide which "memos" are actioned. They had something similar in Bluetown, but this child apparently feels it to be tokenistic, and yet again we heard the complaint of teachers not listening:

We've got like a change box... Like you could put a thought in it as long as it was sensible like... And, then the teachers could read them and then they could like actually pick the house captains or something. But, they don't listen. You could have a really good idea but they don't listen (Bluetown 11- to 15-year-old).

Home rules

In general children report having more of a say in rules at home than at school. They certainly say they have more opportunity to talk to their parents about something they are not happy with, and seem quite confident in being able to do so. But even here, their power is limited:

I get shouted at when I say I don't want to do something (Yellowtown nine- to ten-year-old girl).

The difference between home and school consequences was clear:

Girl: There isn't a rule there [at home] really? It's just something that you do. I don't think there is actually a rule that says...

Boy 1: There isn't a punishment for shouting at your parents is there.

Boy 2: Well there is, you get grounded.

Boy 1: But not like at school like getting kicked out of school and all that.

There was one place where many children reported having some control - their bedroom at home: 
Yes you can have the rules of your bedroom, don't come in my bedroom unless you knock on the door (Metstown seven- to nine-year-old girl).

Though even in this area there are limits, in particular with a rule that they should tidy their room.

Child 1: Sometimes you can show that you're angry cos like you start getting in a mood or something and they start shouting at you.

Interviewer: So what happens when you start shouting? Does that change anything?

Child 1: No.

Child 2: You get grounded.

Child 3: You just get into more trouble. (Yellowtown nine- to ten-year-olds).

Though children have found alternative ways of avoiding compliance with their parents:

You can always look at your mother in a certain way... Like this... and she'd let you do things (Yellowtown eight- to nine-year-old girl).

\section{Community involvement}

\section{Things children liked about their community}

Children were asked to tell us about their community and neighbourhood, about the availability of recreational activities and voluntary services, and their participation in them.

In general children were positive about the places where they lived, the positive aspects being the first things which they mentioned. Some mentioned aspects of the place as being good about where they lived, other identified people and neighbours as important.

Place

...it's fun cos when you go down the beach in the summer there's all sorts of activities like the pier, cinema, bowling and they have these trampoline thing (Greenstown eight- to nine-yearold).

... is very nice... it has a lot of scenery (Bluetown 11- to 15-year-old).

...is a good place in the summer cos we go everyday everywhere like the beach (Pinkstown six- to seven-year-old).

People

It's good to live round here because you are near to the school and you get earlier to school and also you have good neighbours that are kind to you and like I have a neighbour and sometimes she gives me presents (Metstown 14- to17 year-old-girl).

... In the summer you can share your neighbours' pool (Yellowtown seven- to 11-year-old).

...is a friendly neighbourhood. Neighbours look after each other.' (Yellowtown seven- to 11year-old).

For ages in Year 3 cos my mum had lung cancer and... erm... cos she was shaking she couldn't move, I went over to my next door neighbours' house and she phoned the police and looked after me and my mum. No not the police, the ambulance... Until the ambulance came and then he looked after me for the night until my Nan came (Greenstown eight- to nine-yearold).

\section{Things children did not like about their community}

When the children were asked what they didn't like about their community, almost all children had something negative to say: "not that nice", "bad", "dull", "boring", "dump", "smelly", and "unsafe", were 
all words used to describe it. At the same time some children felt rather protective of their community, and defended their views.

Child 1: I hate the place.

Child 2: They're gonna get the wrong impression ...

Child 1: It is an area full of crime.

Child 2: I think you're giving them the wrong idea about the place... It's not really that bad... maybe a little...but not a lot...

Child 1: If you're sensible it's safe. (Bluetown 11- to 15-year-olds)

On balance, the children had much more to say about the problems of the areas than about their good points. Again we can distinguish between features of place and those of people.

\section{Lack of facilities}

The complaints about place were generally about lack of things to do for the older children, and safe places for them to play for the younger ones. Community safety is considered later in the report, so the views of the older children are presented here.

It is boring in winter, unless it's snowing (Bluetown 11- to 15-year-old).

Child 1: There's quite a few things to do.

Child 2: Oh yeah. What part of the planet do you live in?

(Greenstown 14- to17-year-olds)

Nothing much to do apart from the park and the shop and the pub. There is a fish and chip shop and that's it (laughing) (Pinkstown 13- to14-year-old) .

Child 4: ...l go outside and sit outside the phone box.

Interviewer: You're joking. What do you do there, listen to people's conversations?

Child 4: No, we just go to the phone box and phone people, there is nothing else to do. (Pinkstown 15-year-old)

Interviewer: What would you like to do? What would you like to get involved in?

Child 1: Anything's better than nothing. l'd do anything me.

Child 2: I would

Interviewer: Like what?

Child 2: Like pictures. I love them. Anything, anything.

(Pilotstown 13- to15-year-old girls)

People

There were quite a lot of people that children were concerned about in their neighbourhood. Some of them were identified groups, some were individuals, and some made general statements about the neighbourliness (or not) of people in the area.

No one helps each other around my area, it is just too packed with violence... when somebody falls down it is only their brothers or sisters that will come and help. But, if someone deliberately hits someone and was beating them up, everyone around would just like, if it was outside of the area and if they saw someone beating someone else up, they would just walk past and not do anything (Metstown nine- to ten-year-old).

Sometimes you do get scared because sometimes the gypsies they scare you (Metstown 14to17-year-old boy).

We don't go to the grown ups ... because some grown ups don't really believe the children that live around our block because it is so influenced with violence, so they don't really believe us and they say that we're doing it and they would probably call the police (Metstown nine- to ten-year-old).

Bad people should be punished... You can tell the difference between bad people and good people cos the bad ones like they smoke, and look at you, and they're all scruffy... they're 
about 30 or 20. Well, 30... Bad people are quite old... They're usually alcoholic...drug addicts (Yellowtown ten- to 11-year-old).

\section{Teenagers: troublesome or troubled?}

"Teenagers" have been identified as problematic in a number of studies which have talked to children about their neighbourhoods (e.g. Sparks, 2000; Morrow, 2001; University of Sheffield, 2002). Many of the complaints that children made in this study, particularly the primary school children, were about older children in the neighbourhood.

It's not safe... There are all these teenagers up there and like sitting on top of the fences and we all have to go inside... They swear at the headmaster, calling him names. They do it to wind teachers up... They throw things on us... they call us names...! They are boys and girls... they are 14 years old... some will be saying you look like fat, large, odd coloured, or... (Yellowtown ten- to 11-year-old).

There are like big boys that live around my area like 13 to 15 ... They hang around and get oil and put it on the floor and set them on fire on my block (Metstown nine- to ten-year-old).

There's really nasty boys and they come up to mine and C.'s close and they start smoking and put all alcohol on top so we're not allowed to play in... we have to play in one certain area... And, one of them's my next door neighbour. My mum goes in any my next door neighbour's, you know, his mum and she like talks to him and erm... but she tries to handle her son. She can't handle him (Greenstown eight- to nine-year-old).

They're [teenagers] boys and girls... They're mostly boys. They usually get charged by the police... They get a warning and then they hide... They mostly go at night so they don't get caught by adults.... They sometimes come to our school to aggravate the teachers. They throw little cap bombs at us (Yellowtown ten- to 11-year-old).

Erm... cos my mum and dad have split up well ...erm... he's moved ... cos there's loads of like horrible people living on the street got all drugs and everything and my dad keeps mentions that he hates going to Greenstown every time he has to pick us up from there and go all the way to $C$... cos like there's all these boys who've got motorbikes and they even get their brothers' car, riding them down the ..... (Greenstown eight- to nine-year-old).

And there are individual children who are well known in the neighbourhood.

There's this boy. He's my friend's brother. He throws like motorbike wheels in the middle of... the middle... down this hill in the middle of the road and it nearly caused a crash. A car ran over it and went forward like that, smashed the front... His mum slaps him... smacks him, do you know like a mum would do like, hit him on the bum and then... and then... erm... it just doesn't teach him. He just runs out, climbs out of his window and runs away. Then, he was sent to foster home, but he is still behaving badly... He still stays out dead late and... erm... causes trouble... One time he put this cat in a box and set the box on fire... Yes, and the body was in the window and we were all looking at it. It was all shrivelled up... (Pinkstown sevento nine-year-old boy).

At the same time as suggesting that "teenagers" were a significant problem to them, some of the children had suggestions about what might be done about the problem:

I'd like to also go down to like all the teenagers' mums and tell them cos some of them get away with it because it's down to their mums and their mums aren't bothered (Yellowtown nine- to 11-year-old boy).

If I'm in charge, l'd sign a petition to get rid of paedophiles, alcoholics, and bad teenagers.... and give it to the government... (Yellowtown nine- to 11-year-old boy).

Interviewer: So, what sort of things would you like to change?

Child 1: l'd like to make the park bigger like for all of like teenagers to and..

Child 2: $\quad$ l'd like teenagers to be nice to me.

Child 3: I'd like everyone to be friends. Yes, and play games and... 
Interviewer: You'd like to change that. Okay, so say let's take for example making people nice, that's something that you all seem interested in doing... making teenagers nice to you.

Child 2: $\quad$ So, how do you think you could do that?

Child 3: $\quad$ Talk to them.

Child 1: $\quad$ But, not all the time with the...

Child 2: If you like sort of you make friends with them and you start being good perhaps they'll follow. Like say hello when you go past.

(Pinkstown nine- to 11-year-olds).

\section{Children's safety}

Teenagers and the things that they do are clearly a cause of anxiety for younger children and an issue of community safety. The children also presented a litany of other aspects of community safety that impinge on their lives.

... we've got this park... em... some people found syringes down there so l'm not allowed to play down there. I'm only allowed there with big people (Greenstown eight- to nine-year-old).

It's not very nice cos there's all needles everywhere.... This boy he puts his tongue on one, he's only four years old... He never had a clue what it was... (Greenstown 14- to17-year-old).

Have you been down there where all the old houses are? Flags all over and everything. All the grates, lids off the gates. Anybody can fall down them (Pilotstown 13- to15-year-old girl).

Its bad cos there is a park where bad people dispose syringes, cigarettes, and lighters (Yellowtown ten- to 11-year-old).

The place around here is not very safe ... one of our next door neighbours found a knife. She's quite old, she found it outside her backdoor gate and that night she saw someone trying to ... get in the back yard and ... the dogs starting barking and she heard something drop and she saw the person run. When she went out the next morning, there was a knife there and loads of syringes (Yellowtown ten- to 11-year-old boy).

There is the park, ... They say there's loads of like men and they flash at you and all that... They hide in the bushes... And, then you're walking up and they come out and they chase you (Yellowtown ten- to 11-year-old).

\section{People in authority}

When raising issues of their own safety and protection from the concerns which they had raised, the children often referred to people in authority, the inability of those people to deal with the problems, and even the problems which they create. It is worrying that at such young ages they are losing respect for adults, and in particular for some important civic institutions such as the school and police.

\section{Adults}

People say nothing about the teenage gangs... Well, the grown-ups are disgraced... They don't do anything... They harassed my friend... They threw eggs at us... They [adults] say they're [bad people] coming from other areas so no one can tell their names... They come round to here so they won't get into trouble (Yellowtown ten- to 11-year-old).

\section{Teachers}

The teacher tells them (teenage gangs) to go away, but they ignore the teacher so the teacher says just ignore them kids and just leads us away and then they end up going cos of boredness (Yellowtown ten- to 11-year-old boy).

We don't trust the teachers... Why should we...All they do is put us down...(Orangetown nineto ten-year-old).

All teachers they look all nice on the outside, but on the inside they're all mean to you and the staff room is just like a little undercover thing... When you meet them for the first time they're 
like kind and when you're in their class they like... they like start to be horrible (Orangetown ten- to 11-year-old).

I don't trust teachers, they lie about you and then the headteacher believes them, believes the teachers (Whitetown 13- to 14-year-old boy).

I think the school is very boring...And, teachers always suspect you... They blame you for everything... They don't listen to you (Greenstown ten- to 11-year-old boy).

Police

I don't trust the police cos ... Like when someone stole my scooter. And, he goes, "have you got it back?" And, he goes, "yes". "But can you find the person who done it?" and he goes, "Sorry, sort it out yourself" (Greenstown eight- to nine-year-old).

I don't trust some police cos they can be really with those people because you know the Gypsies that live down there, yeah the M., the white police officers that work down in H. they don't do anything to stop them (Metstown nine- to ten-year-old).

I trust the police because once my sister ran away. They came and said they'd find her and they did (Bluetown 14- to15-year-old).

You call a policeman. My uncle one day had a car a new car and it got stolen and the police didn't come. They say we'll come in one hour and two minutes. My uncle waited for two hours and they didn't come. Sometimes they don't care about other people (Orangetown tento 11-year-old).

Young offenders who are critical of the police have been found more likely to be persistent in their offending (Jamison et al, 1999).

\section{Diversity}

In their discussions about the people who live in their area the children frequently and spontaneously brought up issues about people who were different in some way.

The following is an excerpt of some 13- to 15-year-old Pilotstown children's views on what they called "the Bosnians".

Child 1: Yes, I don't bother with them. I don't like them.

Interviewer: Don't you?

Child 2: Who, like who?

Child 1: What you call them?

Interviewer: Asylum seekers.

Child 2: What are them?

Child 1: They're them that sneak into the country.

Interviewer: Do you think that because of what the papers say and what they say on the television or from what you know yourself?

Child 1: From the 'tele', I'm not racist though.

The following is an extract of a primary school children's discussion of people of different colour:

Child 1: Really, they're just the same just a different colour.

Child 2: Yes.

Child 3: Yes, in London... like if you're eating white chocolate and another one is black, you can't offer them or you can get nicked. Like put in prison because...

Interviewer: Say that again, so this is where?

Child 3: In London. Where I used to live.

Interviewer: Right.

Child 3: If someone's eating black chocolate... yes, like a Chinese girl or black, and a white person's eating white... yes. If you offer a white person... If you offer a black person a white one, you can get taken away.

Interviewer: Oh. 
Child 1: That's really weird.

(Pinkstown nine- to 11-year-olds)

There were some negative views about "Gypsies" from a range of locations.

We don't see the Gypsies as part of the community cos they stay with each other (Pinkstown 14- to15-year-old).

Gypsies, they think bad things are funny (Metstown 14- to17-year-old girl).

Gypsies have their own community... They don't let people in (Pinkstown 14- to15-year-old).

The following excerpt from a group of 14- to 17-years-old in Bluetown shows how they witness racism in their neighbourhood:

Interviewer: What sort of people live around here?

Child 1: In C. Road, there's Klu Klux Klan.

Interviewer: Is there, so are there black people around here?

Child 2: Yes, some.

Child 3: They're moving soon.

Interviewer: Are they? Why are they moving?

Child 3: They are afraid of the Klu Klux Klan.

and later on in the discussion:

Interviewer: Do you think some people around here are treated worse than other people?

Child 1: Yes.

Interviewer: And, which people are they?

Child 1: Coloured people.

Child 3: Coloured people.

Interviewer: Are they?

Child 3: There's some people down my street who get bullied all the time... get picked on, get blamed for stuff. My friend, he's coloured... He was trying to stop this fight like... and he stopped it and then this man, one person's father, said, "Why did you stop it?" and he said, "Because they were battering each other" And, then he said, "Just go away", and then he phoned the police about him and said that he was doing the stuff to his kid. He wasn't....

But not all views of other groups were negative.

Some people don't like Irish people... I think Irish families are no vandals. They are just wild and want to have fun. (Bluetown 11- to15-year-old).

Some of the children who took part in the groups described their personal experience of discrimination.

When we used to live in the white area... we came out of the house and grandma were... on the wall and she got so mad the house took her ages to do... and every morning it was just graffiti on the walls on our house. So, every morning we had to get up early and clean the graffiti (Metstown nine- to ten-year-old).

... cross the road from us they usually say, "good morning" to the people they like. ... every Saturday when I come out and when I pass them, I say good morning, and they just ignore me, they walk right past us. They are racist. They don't like black people (Metstown nine- to ten-year-old).

... she has a little girl ... but, her mum don't let her play with me because she doesn't like black people... (Metstown 14- to17-year-old girl).

The research provided us with an opportunity to talk to a group of young traveller children to learn about their experiences of exclusion and discrimination. 
We gypsies have a different language to you, Agorgy... a lot different language...we aren't allowed to speak it in school...It's because they don't understand and they're afraid that we say something nasty... I hate all this... (Pinkstown nine- to ten-year-old).

I hate the teachers... I think they should sort them out... They should like put them in prison cos they make fun of us all the time... (Pinkstown nine- to ten-year-old).

I'm sick and tired of when I go past school and that people keep shouting at me "gyppo, gypрo, gypро" (Pinkstown nine- to ten-year-old).

Other discriminations mentioned were on the basis of gender and age:

I don't like to have a teacher who'll say... when a girl and boy at school got in trouble, he doesn't just let the girl go, he just send them outside the office... and the boys get in trouble all the time (Orangetown ten- to 11-year-old boy).

You're not... say you were having a... girl aint allowed down the boys yard and... erm... at dinnertime and they should be allowed to play football up here. They go like on this little bit here and people go skipping on here and... sometimes they play rounders and teachers give them a row, the dinner ladies. We're not allowed down the boys' yard but boys are allowed in our yard (Bluetown 14- to17-year-old girl).

Nobody wants to listen to kids and the old people. No one trusts children because they smash windows. But, I am not friends with children who break windows (Bluetown 11- to15-year-old).

Year nine is the worst sort of year in the school... we're the most left out... sort of thing... Years and years ago... The only reason that Year nine can't have a common room is because years ago Year nine did have a common room but they mistreated things. Because you know, we're Year nine now, we're completely different people and they're still looking back on what those Year nine did and they say that we can't have anything... (Pinkstown 13- to14year-old).

\section{Social capital}

Social capital is generally taken to refer to social networks and reciprocity within a location as well as formal and informal 'caring' relationships (Putman, 1993). This research found a wide variety of involvement among the children in this study, demonstrating that such foundations are laid at an early age.

\section{Clubs}

Formal clubs and places to go and meet friends were absent in many of the locations visited, although Yellowtown children did refer to several.

You're not allowed to AA club if you're three years old or under, but they are up to 15 years old allowed (Yellowtown seven- to eight-year-old).

The cookery club is in this school downstairs on a Tuesday, Mrs. O. takes you for that because he doesn't do staff meetings (Yellowtown seven- to eight-year-old).

There's like the D. 's Youth Club. There's like a couple of youth clubs that you can go to play pool and football and stuff but it's got strict rules... It anyone hits you in the youth club, they'll just chuck them out. They won't lay a finger on them, they'll just say get out... there's no swearing and nothing.. You have to pay like 50 pence or something to get in, though... (Yellowtown ten- to 11-year-old).

\section{Voluntary activity}

A small number of young and old children described how they performed different needed services with their peers and for their community such as marching to save their school from closure, picking 
up litter, helping the elderly, walking children, babysitting, cleaning stables and washing cars, and even peer tutoring other pupils in their classroom. A few formal activities were organised, but most were informal "neighbourliness".

Organised

We did a march from $P$. all the way to $R$. and all the way back... and loads of people were beeping and all. And, we had a sign saying... We kept on shouting out, "save our school". We also got on the news... We went up to County Hall and we made a song up, didn't we (Pinkstown ten- to 11-year-old).

I've just started my Duke of Edinburgh award. And, there's a lot of stuff in that which is community service and all that... But, I suppose in a way it isn't because I'm getting something out of it in the end...Although, I'm not actually sort of paid to do it... It's pretty open... (Pinkstown 13- to 14-year-old).

In textiles... we made our cushions we took them up to the hospital for the old people's ward thing. We sang for them as well (Pinkstown 14- to15 year-old-boy).

Informal

My next door neighbour, he's got like bad arthritis and I walk his dog for him... (Pinkstown 13to14-year-old).

I babysit my cousin... Like when they cry you don't know what to do so I put him in his cot and he went to sleep then (Pilotstown 13- to 15-year-old).

We pick our garbage and put it in the bin so the wind does not blow it away (Yellowtown tento 11-year-old).

We always clean our street on Saturdays (Yellowtown seven- to eight-year-old).

My mother and I do shopping for this old lady (Pinkstown nine- to ten-year-old).

My mum cleans old people's houses (Pinkstown nine- to ten-year-old).

I help those elderly living next door who can't carry a lot of shopping bags (Pinkstown nine- to ten-year-old).

We help each other in classroom... like if someone does not know how to do something... like, we help each other... (Yellowtown ten- to 11-year-old).

I go keep them [elderly neighbours] company sometimes. My next door neighbour, the man, his wife is hurt, you know... and she stays at home and I go with her husband to keep him company when he goes shopping (Pinkstown primary school child).

On a Saturday or a Sunday after I come home from rugby there's this woman and she's old like, she's got like this thing when she walks. I always go to the shop for her sometimes and she always gives me money but, I put it on her desk or something like that and she doesn't see it and then a light bulb won't work and I call my friend and he lifts me up and I took the light bulb out and put it back in for her and she keeps giving me money all the time but, I don't take it (Bluetown 14- to 17-year-old).

Reasons to help people/volunteer

In one group the discussion identified the reasons that young people undertook the voluntary activities, revealing that though some of the voluntary services are integrated into the school programme, and in some instances children are offered incentive stickers and badges as a form of appreciation and reinforcement, personal fulfilment is an important incentive for these children in Bluetown:

People remember you for the good things. 
It's, I don't know, you just feel a bit, like I don't know, you just feel really good about yourself because you've given back.

It feels good to see all the smiling faces and stuff.

When they see you the next time, they can't say they're [children] up to no good they say...

Paid work

A surprising number of older children reported having some form of paid work, reflecting their willingness to find means of overcoming the deprivation in the area.

I work in the butchers. I just clean up and wrap the meat and stuff like that. I do it to get money for clothes and stuff. Sometimes it keeps you occupied when you've got nothing to do. (Whitetown 13- to14-year-old boy).

I work... you don't have to ask your mum for money. Or, when you go shopping with your mum when you pick something up and she says you can't have that, you have to pay for it yourself (Whitetown 13- to14-year-old boy).

I play the black pipes and I get lots of money for doing that at weddings and all sorts... (Pinkstown 13- to14-year- old).

Not all children were happy with the arrangements, however: some feel exploited.

I think it is a rip off. When I used to do it, a paper round we used to do something like 350 hours and we only used to get about 200 quid and I had to fold them and put them in my sack (Whitetown 13- to14-year-old boy).

You do less hours because you have to go to school and that... Because you are not old enough to get the minimum wage... Why? Because you can't fight back... Because they think we're stupid and you won't be able to add the money (Whitetown 13- to 14-year-old boy).

\section{Political literacy}

\section{Knowledge about politics}

Many of the statements made by children about politics and politicians portray a cynicism and lack of trust at a very early age. This could lead to apathy as they become old enough to vote.

I don't like the government... the government was gonna take away our trailers from the site [British Gypsy Travellers' site] but... put a stop to it. My mum was also going to be taken off the site... (Pinkstown nine- to ten-year-old).

I don't trust politicians because they are just trying to make more money for themselves, they put money on petrol and stuff like that. Say, if you wanted something built like a park or something, they wouldn't do now that, they just wouldn't. I've been waiting for about five years (Whitetown 13- to14-year-old boy).

In some ways, I do trust the government because sometimes they do things that are right but sometimes they just say they couldn't do it, and they don't do anything about it. They just want to make people feel and just feel comfortable, make them feel happy that the government is going to do something so you will have nothing to worry about (Metstown nineto ten-year-old).

Children demonstrate an understanding of the difference between central and local government, though not always with positive views:

I don't think the politicians or the council protects me... When the blind politician, David Blunkett... When... erm... he went... on this new thing they graffitied this wall about heroin use and then just before his visit, his council came and plastered it back up and then the night 
after there's no use trying to cover it up, and that true because... isn't it? So it doesn't show the truth about... cover stuff up (Bluetown 12- to13-year-old boy).

We've written to the local council two years ago to get the park cleaned up... But, they turned us down (Whitetown 13- to14-year-old).

The city council can get involved. The police can try and stop, try to find the people who are actually doing it and stop it. And, the "safety people" [police officers who remove dangerous syringes and other objects from public places]... We keep writing letters and that but they just won't take, they have to see if their selves... (Greenstown eight- to nine-year-old).

Some of the groups were asked if they should be able to vote for the government, and the general response from children was that they felt they were too young, or didn't know enough:

You have to be mature to vote (Bluetown 11- to15-year-old).

I wouldn't vote cos I don't know about the issues (Bluetown 11- to 15-year-old).

I don't think it is a good idea to vote cos I would end up electing the wrong person (Orangetown 11- to 12-year-old).

\section{Sources of information}

It is often suggested that children are not interested in current affairs, but that is not the picture which emerged from this work. Unsurprisingly, the television was their main source of information, and many of them reported watching the news or documentary programmes. There was also a substantial interest in newspapers and the radio as a source of information.

I read the newspaper, the Sun... I read the cartoon bit and look what's on in the cinema (Pinkstown seven- to nine-year-old).

I read the Daily Mail, Express, and the Argos (Greenstown eight- to nine-year-old).

I like watching the news cos I'm interested in the weather sometimes and I like to know what's going on cos I'm a bit nosy me (Greenstown eight- to nine-year-old).

I've seen it with New York when the plane crashed and l've been watching that since and like I'm really interested in... like I wanna see if New York's winning or Afghanistan in case... it might spread over to our country and that (Greenstown eight- to nine-year-old).

I watch the news on TV...There might be something important that everybody needed to know. Like if there's like a bomb in the town and you don't know and you've got go in there and it just explodes? (Orangetown nine- to ten-year-old).

I read the newspaper... [name of local paper] cos it gives more information than the TV (Pinkstown ten- to 11-year-old).

I read the newspaper to see who won the football match (Pilotstown ten- to11-year-old).

Television doesn't lie. Newspapers sometimes actually add on their little bits to make it like... like more interesting so more people read it (Pilotstown ten- to11-year-old).

I listen to the radio cos it is more interesting. They tell you what happens everywhere not just in here but in the world (Pilotstown ten- to 11-year-old).

I like watching documentaries about people lives. Not like wild life documentaries, documentaries about people with problems and stuff because I'm nosey (Pinkstown 14- to15year-old).

I watch the headlines on TV to see if there's any happy news... It's educational as well as... (Bluetown 14- to15-year-old) . 


\section{Citizenship}

As the final discussion point in the social and moral responsibility sessions, the researchers asked the children if they knew what a citizen was, and what made a good citizen.

The majority of children knew the word "citizen" and could explain where they knew it from. Television and films were frequently cited, often naming a film or television programme and giving the context in which "citizen" was used. Other contexts suggested were "citizen's arrest", "when you go to...you know when you get your passport..", "British citizen". Rarely was school suggested as a source of information about this, and when questioned directly about whether they had been taught anything about citizens at school they said no.

I've heard in the Star Trek one alien say I am a citizen of the planet...But I'm not sure what that means (Yellowtown seven- to eight-year-old).

It was not generally so easy for them to describe what they thought "citizen" meant, especially for the younger children. Those at primary school have quite a general understanding of citizenship based on notions of belonging and helping others. The following are examples from ten- to 11-year-old boys in Greenstown:

it's like you are a citizen of a country

is it like if you're a member?

it's where you live

a person helping others when they are in trouble

You have to be born in a country to be a citizen of a county (Yellowtown seven- to eight-year-old boy).

Some suggestions were down to earth:

you're a normal person, a good person (Yellowtown seven- to eight-year-old).

and others hard to live up to:

Citizens are saints (Metstown seven- to nine-year-old).

Children who were not born in Britain, or had parents who were not born in Britain, were more likely to discuss residence and earning the right to be a citizen.

Boy: No, my mum was born in Iran.

Interviewer: So, is your mum a citizen of Iran or of Britain?

Boy: Britain now 'cause she lives here.

Older children introduced the idea of responsibility to pay taxes and abide by the law.

A citizen is someone who "abides by the law, goes to work and does everything good", "pays tax, bills", "no crime", "charity business" and "no trouble, just do their work" (Metstown 15- to 19-year-old boys).

This is a more traditional conceptualisation, about obeying laws and doing what society asks, and yet controversial within this group, where it was suggested that a good citizen was a "goody goody" and "someone who does everything right". However, the general consensus even among this group was that it is "just a normal person, not everyone is a good-goody".

There was little difference between the definitions provided of a "citizen" and a "good citizen" suggesting that the concept of "citizen" inherently includes notions of "good". The younger children felt a good citizen was:

a good person 
they're like good people who help the town and stuff.

never in teachers', bad books, never fighting (Metstown seven- to nine-year-olds).

like people keep the law or something, like laws and be kind to each other and that. caring for the community.

and don't destroy people's property (Yellowtown nine- to ten-year-olds).

A few young children described what they thought were bad citizens:

a bad citizen is like a criminal or something (Greenstown ten- to 11-year-old boy) . ..rob cars and stuff like... (Yellowtown nine- to ten-year-old).

The session ended by asking children if they thought they were good citizens, and most thought that they were "cos I'm dead kind" and "I'm a good citizen cos when .. erm.. I helped this man..." (Yellowtown nine- to ten-year-old). Some children, however, thought that they were too young to be citizens, and others thought that they were citizens but not necessarily always good citizens (Metstown, older groups). 


\section{Conclusions}

At one level, there is nothing unusual in what children told us about rules. It's much the same as one would expect a reasonable adult to say. Where they know what a rule is, the reasoning behind it, the consequences of non-compliance and the certainty of the consequence, then they are likely to comply, even though they may not necessarily agree with the rule. What is noteworthy is that these children and young people demonstrated the same range of views and opinions as similar groups of adults might have done. Their skills and articulation may not be well developed, but it may be that the views of many adults would be similarly straightforward. The ideas put forward were clearly well understood by the young people, and not simply repetition of adult or media views.

It is important that children are given the opportunity to develop these ideas at an early age, to hear a range of arguments and other options, and to be able to rehearse situations - learning to be a good citizen involves being able to discuss important issues. It should not be thought that children are too young to have a reasoned view about such issues, nor that they are uninterested in discussing and learning more about them.

The following are key points with policy implications which emerged from this piece of work.

\section{A safe place to grow up}

The children's reports in this study present a picture of communities that are not safe places for children to grow up. The deprivation in these neighbourhoods results in them focusing on surviving day to day in a very different environment to that in which many children grow up. All children have their movements restricted because adults, rightly, try to protect them from harm (Jeffs and Smith, 1999), but the dangers described in deprived areas are much greater. Perversely, the resources available to individual families and to the community in these areas are much less than the norm, and thus they cannot buy alternative spaces for children to be safe. Local authorities and statutory agencies may see the need, but do not have the resources to either provide alternative facilities or improve the safety of those that exist. The result is that the movements of children in these localities are more severely restricted, the range of options open to them is narrowed, and they face a much greater range of immediate and longer term risks.

In these circumstances there is a danger that alternative sources of funding are sought, such as On Track and Children's Fund, and that these are used to provide services which are available as mainstream basic provision in less deprived areas.

\section{Diversity}

Children reported some genuine misconceptions about people from different backgrounds, particularly at a very early age. The seeds of racism can easily germinate here. School has a role in finding ways for children from different backgrounds to gain some understanding of one another's cultures. This does not mean teachers having to learn and teach it all - many of these schools have a rich mix of cultures amongst the children and their parents who could be enlisted to help with this process.

Tronya and Hatcher (1992) blame schools for a faulty approach to cultures: instead of introducing cultures as similar to other cultures, they are presented as exotic "strange" cultures. What is needed is to establish a better understanding of different people's lifestyle, religion, culture, and tradition.

Schools with largely homogeneous communities may need to be especially creative in addressing issues of diversity, particularly in acknowledging the importance of all children having an understanding of different cultures. This is even more so where children do not have direct contact with people from other cultures. 


\section{Education for citizenship}

The introduction of citizenship as a component of the National Curriculum for secondary schools confirms the view that the school is an important arena for children to develop their understandings and appreciation of the central tenets of citizenship. The evidence from the children in this research is that significant opportunities are being lost. The most important learning point is that children need to have the opportunity to live and experience 'citizenship' in their day to day life in school. In fact it is often forgotten that school is the first formal organisation that most children are part of. To enable them to really appreciate the important concepts and prepare them to be able to apply these effectively as they grow older, they need to have them demonstrated by the adults in school around them, and to experience them in the structure and organisation of the school. So often the children and young people, even at a very young age, are sceptical of participative initiatives in schools because they detect tokenism within them. Children do not trust the teachers in their schools, because they often feel the teachers do not respect them. Community involvement for children should include involvement with their school community, which involves understanding how it is run and decision are made.

Fundamental to the notion of a "citizen" is the ability to make reasoned choices about their life and act in a way, which is beneficial to all. It is about having some control and autonomy. The approach of many schools/parents is authoritarian controlling and limiting of the behaviour of children. This creates a fundamental paradox. How can children learn to be in control and make the right choices without having the opportunity to practise?

The children in this study feel that they have little control in their lives and that their options are narrow. This feeds into the mentality of "no choice" and "I had to" presented by many young offenders as a reason for their behaviour. The success of many cognitive behaviour programmes and thinking skills courses for adult and young offenders shows that these skills are important and can be learned. It is a waste of valuable resources, not to mention young lives, that this sort of learning comes after a problem becomes apparent. Incorporation of some of these techniques within a structure which enables them to implement that learning, even at a simple level, could pay enormous dividends in the long run. A good environment for this is the primary school, and an appropriate structure is the national curriculum.

Similarly, work with young offenders has shown the value of so called "pro-social modelling", which fairly simply means leading by example. The probation service has been at the forefront of developments in this area and discovered that the modelling needs to go much further than individuals. To be truly effective pro-social modelling must be embedded in the situation. Some of the principles could usefully be applied in the training of teachers and headteachers.

This research shows that children can and do present reasoned arguments against school rules but they have rarely felt able to address them in school. Where they have suggested trying to do something the means they have chosen have been inappropriate. Schools could help children to become active citizens by having a system, which enabled the children to have a say in the rules of the school and, importantly, ensure that the children felt that their comments had been heard and properly listened to. There is evidence here that well run participative school councils can be effective. Speak (2000) similarly recommends greater real involvement for children in decision making following a study listening to children's views.

A technique which would be valuable for children to learn is negotiation skills. Many of them simply refuse to do something they object to and are punished as a consequence. This seems to be because they do not know how to change things and so simply refuse. Learning negotiation techniques and skills which they can apply in a range of situations would be empowering for them in a range of contexts and avoid potentially conflictual situations for both parents and teachers.

Children are aware of the rhetoric around citizenship, even though they may not have a full understanding of the term. However, sometimes the simplest definitions are the best, as this description of a citizen from a seven- to nine-year-old girl in Metstown:

they're really good people who help each other, and they treat one another with respect. 


\section{Justice}

The younger age groups are sure that stealing any item is wrong. The older groups presented more tolerance, and even approval of stealing minor items of little value, but when the item involved is more valuable (such as a CD player) there is general disapproval here too. Children and young people clearly have a moral code which they can articulate and apply.

Within this moral code children and young people have a very strong sense of fairness and are quick to spot what they see as unfair treatment. Reasons for the treatment may be completely reasonable, but frequently these are not shared with children. Nor are the views of children actively requested or listened to. Children often have well balanced views, can see alternative positions and present cogent arguments for them. A good example is related to a quite common complaint from children, particularly in primary school, about not being able to play on grass. They understand the reasoning, that they could get muddy and trail the mud into buildings. Their suggestion, in at least two of the areas visited, was to have an alternative way - one group suggested being to be allowed to play on the grass when it's dry but not when it is wet, and the other suggested replacing the grass with all weather synthetic material:

I think you should be allowed to play football on the grass. You should be allowed anytime no matter if it's wet or dry. We should get some of that astro turf instead (Greenstown ten- to 11year-old).

I disagree with the rule that does not allow us to play on the grass... There's two rules... There's two... We would be allowed to play on the grass when it's dry and we wouldn't if it's muddy (Orangetown ten- to 11-year-old).

This research study demonstrates that even very young children have a clear understanding of the principles of restoration and reparation and they identify and empathise with the victim. This lends support for the value of many of the restorative justice changes being introduced and implemented for young offenders. At the same time they emphasise the need to involve the victim directly and avoid tokenistic restorative techniques such as were in evidence in the piloting of reparation orders (Dignan, 2000; Holdaway et al, 2001).

\section{Politics}

Children's cynicism about the political system could be related to lack of knowledge or to picking up the views of adults around them or the media. Having the opportunity to engage in a reasoned discussion about issues which concern them (such as who makes decisions about traveller sites and what happens to the tax revenue from petrol), may help children to understand the political and civic systems that affect their lives and their role in being able to influence these processes. This is crucial to active citizenship.

Crick (DfEE, 1998) outlines the aim of citizenship education:

We aim at no less than a change in the political culture....for people to think of themselves as active citizens, willing, able and equipped to have an influence in public life and with the critical capacities to weigh evidence before speaking and acting... (p7)

The results from this research demonstrate that encouraging children to participate as citizens may not be comfortable for schools and politicians - an active citizen may well be a critical citizen. 


\section{References}

Banks, M. E. A., (1992), Careers and Identities. Milton Keynes: Open University Press.

Barker, G.K. and Rich, S., (1992), 'Influences on adolescent sexuality in Nigeria and Kenya: Findings from recent focus group discussions', Studies in Family Planning, Vol. 23, p.199-210

Bhavnani, K., (1991), Talking Politics: A Psychological Framing for views from Youth in Britain. Cambridge: Cambridge University Press

Bickmore, K., (2001), 'Student Conflict Resolution, Power 'Sharing' in Schools and Citizenship Education', Curriculum Inquiry 31: 2 (The Ontario Institute for Studies in Education).

Blackman, S., and France, A., (2001), 'Youth marginality under postmodernism', in Stevenson, N. (ed.) (2001), Culture and Citizenship. London: Sage.

Blackstone, W., Sir (1765), Commentaries on the Laws of England. Oxford: Clarendon Press.

British Youth Council, (1995), M-Power: Young Voter Registration Briefing, London: BYC.

Buckingham, D., (2000), The Making of Citizens: Young People, News and Politics. London: Routledge.

Cambridgeshire Travellers Research Project. Travellers and Social Policy: A Suspect Population? Available at: Http://www.camcnty.giv.uk/sub/resrchgp/travel/susp.htm. Accessed April 2, 2002.

Camina, M., (2004), Understanding and Engaging Deprived Communities. RDS Online Report OLR08/04, Home Office: London

Carli, L., (1989), 'Gender Difference in Interaction Styles and Influence', Journal of Personality and Social Psychology, Vol.56, No4, p.565-76

Charlesworth, L.W. and Rodell.M.K., (1997), 'Focus Groups with Children: A Resource for Sexual Abuse Prevention Program Evaluation', Child Abuse and Neglect, Vol.12, No.12, pp1205-1216

Christensen, P. \& James, A., (2000), Research With Children: Perspectives and Practices. London: Falmer Press.

Coleman, J., (2000), 'Young People in Britain at the beginning of a new century', Children \& Society, Vol. 14, pp230-242.

Crick, B., (2000), Essays on Citizenship. London and New York: Continuum.

Croft, C.A. and Asmussen, L., (1993), 'A developmental to sexuality education: Implications for medical practice', Journal of Adolescent Health, Vol. 14, p.109-114

Department for Education and Employment, (1998), Education for Citizenship and the teaching of democracy in schools: Final Report of the Advisory Group on Citizenship. London: DfEE

Dicey, A. V., (1950) (reprint of 1885 edition), Introduction to the Study of the Law of the Constitution. London: Macmillan.

Dignan, J., (2000), Youth Justice Pilots Evaluation: Interim Report on reparative work and youth offending teams, Occasional paper. London: Home Office.

France, A., Hine, J., Armstrong, D. and Camina, M., (2004), The On Track Early Intervention and Prevention Programme: From Theory to Action. London: Home Office

Gilligan, R., (2000), 'Adversity, Resilience and Young People: the Protective Value of Positive School and Spare Time Experiences', Children \& Society, Vol. 14, pp37-47. 
Greenbaum, L.T., (2000), Moderating Focus Groups. London: Sage

Harden, J., Scott, S., Backett-Millburn, K. and Jackson.S., (2000), 'Can't Talk, Won't Talk?': Methodological Issues in Researching Children', Sociological Research Online, Vol.15, no.2, $<$ www.socresonline.org.uk/5/2/harden.html>

Heath, A. and Jowell, R., (1997), 1997 British Election Survey (interim version), [computer file], Colchester, Essex: Data Archive.

Holdaway, S; Davison, N; Dignan, J; Hammersley, R; Hine, J and Marsh, P., (2001), New Strategies to address youth offending: The National Evaluation of the pilot youth offending teams, Occasional Paper No 69. London: Home Office.

Home Office (2001), Citizenship Survey: Progress Report No 1.

Houghton, S., Durkin, K. and Caroll, A., (1995), 'Children's and Adolescents awareness of the physical and mental health risks associated with tattooing: A focus group study', Adolescence, Vol.30, p.971-988

Howard, S. and Gill, J., (2000), 'The Pebble in the Pond: children constructions of power, politics and democratic citizenship', Cambridge Journal of Education, Vol. 30, No. 3, pp. 357-378

James, A. \& Prout, A.,(1997), Constructing and Reconstructing Childhood. London: Falmer Press.

Jamison, J; Mclvor, G and Murray, C., (1999), Understanding Offending Among Young People, Social Work Research Findings No 37. Edinburgh: Scottish Executive Central Research Unit.

Jeffs, T.; and Smith, K., "The Problem of 'Youth' for Youth Work." Informal Education Encyclopaedia. Available at: Http://www.infed.org/archives/youth.htm. Accessed in February 24, 2002.

Jones, G., (1994), 'Family Support for Young People: A Research Report', Edinburgh, Centre for Educational Sociology, University of Edinburgh in Coles, B., (1995), Youth and Social Policy: Youth Citizenship and Young Careers. London: UCL Press Limited.

Kennedy, C., Kools, S. and Krueger, R., (2001), 'Methodological Considerations in Children's Focus Groups', Nursing Research, Vol. 50, No. 3, pp. 184-187

Kitzinger, J., (1995), 'Introducing Focus Groups', British Medical Journal, July 29

Krueger, R.A., (1988), Focus Groups: A practical guide for applied research. London: Sage

Kohlberg L., (1983), Moral Stages: a current formulation and a response to critics. London: Karger

Kruger, A.C. and Tomasello, M., (1986), 'Tranactive discussions with peers and adults', Developmental Psychology, Vol.22, p.681-685

Lassiter, U, Wolch, J.R. and Brownlow, A., (1998), 'Attitudes Towards Marine Wildlife: Designing a Focus Group Analysis for Culturally Diverse Settings', Working Paper+5, USGS-TR-01-99

Madriz, E., (2000), 'Focus Groups in feminist research' in Denzin, N.K. and Lincoln, Y. (eds), Handbook of Qualitative Research. Thousand Oaks, California: Sage

Marshall, T. H., (1950), Citizenship and Social Class and other Essays. Cambridge: The Syndics of the Cambridge University Press.

Merton, R.K., Fiske, M. and Kendall, P.L., (1990), The focused interview: A manual of problems and procedures $\left(2^{\text {nd }}\right.$ ed. $)$. London: Collier Macmillan

Morgan, D., (1988), Focus Groups as Qualitative Research. London: Sage

Morrow, V., (2001), Networks and neighbourhoods: Children's and Young People's Perspectives. London: Health Development Agency. 
Morrow, V., (1999), It's Cool...'Cos You Can't Give Us Detentions and Things, Can You?!', in (eds) Milner. P and Carolin. B, (1999), Time to Listen to Children. London: Routledge

Myers, D., (1983), Social Psychology. New York: McGraw-Hill

Osler, A. \& Starkey, H., (2001), 'Citizenship education and national identities in France and England: inclusive or exclusive?', Oxford Review of Education, vol. 27, No. 2 (2001).

Park, A., (1999), 'Young people and political apathy', National Centre for Social Research, (1999), British Social Attitudes: the $16^{\text {th }}$ Report. Aldershot: Ashgate.

Parry, G., Moyser, M., and Day, N., (1992), Political Participation and Democracy in Britain. Cambridge: Cambridge University Press.

Putman, R. D., (1993), Making democracy work; Civic traditions in modern Italy. Princeton, NJ: Princeton University Press.

Qvortrup, J., Bardy, M., Sgritta, S. \& Wintersberger, H., (eds) (1994), Childhood Matters: Social Theory, Practice and Politics. Aldershot: Avebury

Ring, K., (2000), Young Children talking about their drawings: methodological dilemmas, paper presented at the British Educational Research Association Annual Conference, Cardiff University, September 7-10, 2000

Roberts, H., (1993), Safe Schools are no accident. London: Child Accident Prevention Trust.

Roche, J., (1999), 'Children: Rights, Participation and citizenship' Childhood Vol. 6 (4) pp475-493.

Rubin, H.J. and Rubin, L.S., (1995), Qualitative Interviewing: The Art of Hearing Data. Thousand Oaks, California: Sage

Sparks, R., (2000), Moral Education and the cultures of punishment: a study of children's discourse, Children 5-16 Research Briefing No 14. London: ESRC

Sparks, R., Girling, E. and Smith, M., (2000), 'Children talking about justice and punishment', The International Journal of Children's Rights, Vol. 8, pp. 191-209

Speak, S., (2000), 'Children in urban regeneration: Foundations for sustainable participation', Community Development Journal, Vol. 35, No 1, pp31-40.

Stewart D.W. and Shamdasani P.N., (1990), Focus Groups: theory and practice. London: Sage

Tate, A. (2001), 'Winning the Youth Vote', (online). BBC News Online. Available at [http://news.bbc.co.uk/vote2001/hi/english/newsid1254000/1254995.stm] Accessed 13/05/01

The Citizenship Foundation, (1998), Citizenship for All: A Wide Ability Teacher's Resource Guide. Cheltenham: Stanley Thornes Ltd.

The Citizenship Foundation, (2001), Good Thinking: Education for Citizenship and Moral Responsibility, vol. 1, KS3. London: Evans Brothers Ltd.

Tonya, B. and Hatcher, R., (1992), Racism in Children's Lives: A Study of Mainly White Primary Schools. London: Routledge

White, C. Bruce, S. and Ritchie, J., (2000), Young People's Politics: Political Interest and Engagement amongst 14- to 24-year-olds. Published for the Joseph Rowntree Foundation by York Publishing Service Ltd.

Young, L. and Barret, H., (2001), Adapting Visual Methods: Action Research with Kampala Street Children, Area, 33(2): 141-152. 


\section{Appendix: Sample details}

\begin{tabular}{|c|c|c|c|c|c|c|c|c|}
\hline \multirow[t]{2}{*}{ Area } & \multirow[t]{2}{*}{ Location } & \multirow[t]{2}{*}{ Age group } & \multicolumn{2}{|c|}{ Gender } & \multicolumn{4}{|c|}{ Ethnicity } \\
\hline & & & Girls & Boys & 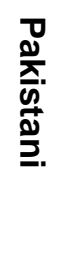 & 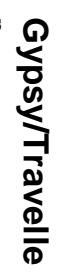 & 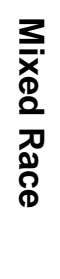 & $\begin{array}{l}\frac{\boldsymbol{w}}{2} \\
\frac{\tilde{n}}{\lambda}\end{array}$ \\
\hline \multirow[t]{3}{*}{ Pilotstown } & Sport Club & $8-10$ & 3 & 3 & & & & \\
\hline & Sport Club & $11-12$ & 3 & 3 & & & & \\
\hline & Youth Club & $13-15$ & 6 & 0 & & & & \\
\hline \multirow[t]{2}{*}{ Whitetown } & \multirow{2}{*}{$\begin{array}{l}\text { Secondary } \\
\text { School }\end{array}$} & $13-14$ & 0 & 9 & & & & \\
\hline & & $13-14$ & 0 & 8 & & & & \\
\hline \multirow[t]{4}{*}{ Yellowtown } & \multirow[t]{4}{*}{ Primary School } & $7-8$ & 3 & 4 & & & & \\
\hline & & $8-9$ & 3 & 3 & & & & \\
\hline & & $9-10$ & 3 & 3 & & & & \\
\hline & & $10-11$ & 3 & 3 & & & & \\
\hline \multirow[t]{8}{*}{ Pinkstown } & \multirow[t]{3}{*}{ Primary School } & $7-10$ & 2 & 6 & & & & \\
\hline & & $8-9$ & 5 & 2 & 1 & & & \\
\hline & & $7-10$ & 3 & 5 & & 8 & & \\
\hline & \multirow{5}{*}{$\begin{array}{l}\text { Secondary } \\
\text { School }\end{array}$} & $10-11$ & 3 & 3 & & & & \\
\hline & & $11-12$ & 3 & 6 & & 1 & & \\
\hline & & $12-13$ & 5 & 3 & & & & \\
\hline & & $13-14$ & 4 & 4 & & & & \\
\hline & & $14-15$ & 4 & 2 & & & & \\
\hline \multirow[t]{7}{*}{ Orangetown } & \multirow[t]{3}{*}{ Primary School } & $7-8$ & 3 & 3 & & & & \\
\hline & & $8-9$ & 3 & 3 & & & & \\
\hline & & $9-10$ & 3 & 3 & & & & \\
\hline & \multirow[t]{4}{*}{ YIP } & $12-16$ & 4 & 2 & & & & \\
\hline & & $10-11$ & 0 & 5 & & & & \\
\hline & & $13-17$ & 0 & 5 & & & & \\
\hline & & $11-15$ & 0 & 5 & 5 & & & \\
\hline \multirow[t]{6}{*}{ Greenstown } & \multirow[t]{3}{*}{ Primary School } & $7-8$ & 3 & 3 & & & 1 & \\
\hline & & $8-9$ & 3 & 3 & & & & \\
\hline & & 9 & 6 & 0 & & & & \\
\hline & \multirow{3}{*}{$\begin{array}{l}\text { Community } \\
\text { College }\end{array}$} & $10-11$ & 0 & 6 & & & & \\
\hline & & $14-17$ & 6 & 2 & & & & \\
\hline & & $14-16$ & 2 & 5 & & & & \\
\hline \multirow[t]{4}{*}{ Bluestown } & Primary School & $8-9$ & 4 & 2 & & & & \\
\hline & Junior School & $9-10$ & 4 & 2 & & & & \\
\hline & Secondary & $12-13$ & 2 & 4 & & & & \\
\hline & School & $11-12$ & 3 & 3 & & & & \\
\hline \multirow[t]{7}{*}{ Metstown } & \multirow[t]{4}{*}{ Primary School } & $7-9$ & 4 & 2 & & & & 5 \\
\hline & & $8-9$ & 5 & 2 & 1 & & & 6 \\
\hline & & $9-10$ & 5 & 2 & & & & 7 \\
\hline & & $10-11$ & 4 & 2 & & & & 5 \\
\hline & YIP & $15-19$ & 0 & 6 & & & & 5 \\
\hline & & $14-16$ & 0 & 6 & & & & 6 \\
\hline & & $14-17$ & 0 & 9 & & & 1 & 7 \\
\hline & & TOTAL & 117 & 152 & 7 & 9 & 2 & 41 \\
\hline & & Grand Total & & & & & & \\
\hline
\end{tabular}

\footnotetext{
* Ethnic backgrounds of children are an approximation based on information from staff and research observations. If blank assume White British.
} 
Produced by the Research Development and Statistics Directorate, Home Office This document is available only in Adobe Portable Document Format (PDF) through the RDS website

Home Office

Research, Development and Statistics Directorate

Communication Development Unit

Room 264

50 Queen Anne's Gate

London SW1H 9AT

Tel: 02072732084 (answerphone outside of office hours)

Fax: 02072220211

Email: publications.rds@homeoffice.gsi.gov.uk

ISBN 1844732401

C Crown copyright 2004 